Wu, B. H.T. and Mazur, M. (2018) Managerial incentives and investment policy in family firms: evidence from a structural analysis. Journal of Small Business Management, 56(4), pp. 618-657. (doi:10.1111/jsbm.12308)

There may be differences between this version and the published version. You are advised to consult the publisher's version if you wish to cite from it.

This is the peer-reviewed version of the following article: $\mathrm{Wu}, \mathrm{B}$. H.T. and Mazur, M. (2018) Managerial incentives and investment policy in family firms: evidence from a structural analysis. Journal of Small Business Management, 56(4), pp. 618-657, which has been published in final form at $\underline{110.1111 / \mathrm{jsbm} .12308}$. This article may be used for noncommercial purposes in accordance with Wiley Terms and Conditions for Self-Archiving.

http://eprints.gla.ac.uk/109817/

Deposited on 18 September 2015

Enlighten - Research publications by members of the University of Glasgow http://eprints.gla.ac.uk 


\section{Managerial Incentives and Investment Policy in Family Firms: Evidence from a Structural Analysis}

by Mieszko Mazur and Betty H.T. Wu

This paper provides evidence that CEO incentive pay mediates the effect of family preferences on corporate investment policy. Our study focuses on the option portfolio volatility sensitivity vega, which motivates the risktaking behavior of undiversified managers. After controlling for factors that affect incentive pay and investment policy simultaneously, we find that one-third of underinvestment in riskier $R \& D$ projects in active family firms can be attributed to a significantly lower vega. Passive family firms allocate more capital to R\&D as opposed to active family firms, and are more active in M\&A deal making. In contrast to many prior studies, pay incentives and families are not associated with capital expenditures. Overall, our empirical results suggest that CEO pay incentives induce investment policy contingent on firm risk. Family CEO incentive pay manifests the family preference for lower risk, especially in firms with higher firm risk. Nonetheless, after replacing family CEOs with outside professionals, investments in both $R \& D$ and M\&A increase, which is consistent with the family preference for extended investment horizons. Interestingly, such a preference seems not to be manifested in incentive pay.

Mieszko Mazur is an assistant professor of Finance at the IESEG School of Management.

Betty H.T. Wu is a lecturer in Accounting and Finance at University of Glasgow Adam Smith Business School.

Address correspondence to: Betty H.T. Wu, University of Glasgow Adam Smith Business School, Glasgow G12 8QQ, United Kingdom. E-mail: Betty.Wu@glasgow.ac.uk. 


\section{Introduction}

Existing academic literature highlights the importance of family firms (e.g., La Porta, Lopez-de-Silanes, and Shleifer, 1999; Claessens, Djankov, and Lang, 2000; Morck, Stangeland, and Yeung, 2000; Faccio and Lang, 2002; Anderson and Reeb, 2003a; Villalonga and Amit, 2006). In terms of prevalence, La Porta et al. (1999) report that approximately 53\% of publicly listed firms around the world are controlled by families. Similarly, Villalonga and Amit (2006) find that 37\% of the U.S. firms listed on Fortune 500 are founding family firms. Firms controlled by families differ importantly from non-family firms. For instance, family firms are more likely to have reduced conflict of interest between managers and shareholders, but greater conflict of interest between controlling and minority shareholders (Chen, Chen, Cheng, and Shevlin, 2010). Furthermore, family firms perform better as compared to non-family firms (Anderson and Reeb, 2003a), they are less diversified (Villalonga and Amit, 2006), and they have significantly different compensation structures (Gomez-Mejia, Larraza-Kintana, and Makri, 2003).

This paper extends existing literature by investigating the relation between family involvement, managerial incentives, and investment decisions in family firms. Prior research notes that large and undiversified shareholders might adopt investment policy based on their own risk preferences and/or their own investment horizons rather than those preferred by other well-diversified shareholders (e.g., Fama and Jensen, 1985; Shleifer and Vishny, 1986; Gompers and Lerner, 2000). Alternatively, some academic scholars argue that blockholders can mitigate managerial incentives to adopt myopic investments (e.g., Edmans, 2009). Anderson, Duru, and Reeb (2012) study the relation between family ownership and corporate investment policy from the perspective of different preferences between family and nonfamily shareholders. They find that family firms devote less capital to long-term investments, which indicates that family firms affect investment decisions by their preferences for lower risk rather than efficient monitoring or longer horizons.

In this study, different from existing research on investment choices in family firms (e.g., Anderson et al., 2012), we examine the new channel through which families exert influence on corporate investment policy. The channel we identify involves managerial incentives, which have been shown to have a more direct effect on investment decisions made by firms. More specifically, we use two generally accepted measures of managerial incentives widely used in the literature: stock option delta and stock option vega (e.g., Core and Guay, 2002; Brockman, Martin, and Unlu, 2010). Stock option delta measures monetary change in manager's wealth when firm's stock price changes. Higher delta should induce managers to expand effort in searching out new 
investment opportunities; however, delta's impact on managerial risk-taking is theoretically and empirically ambiguous (Coles, Daniel, and Naveen, 2006; Hagendorff and Vallascas, 2011). On the other hand, stock option vega measures the monetary change in the wealth of the manager when firm's risk changes. Higher vega should make managers more willing to take risks.

In our analysis, we focus primarily on stock option vega because, in addition to a solid theoretical foundation (e.g., Haugen and Senbet, 1981; Smith and Stulz, 1985), vega provides a straightforward measure of managerial risk-taking incentives with an intuitive appeal: it tells us directly how much the manager will be better (worse) off, when firm risk increases (decreases). Moreover, vega can help explain why some firms spend more on risky investments (e.g., innovation that is key to firm/economic growth). In our study, we aim to understand to what extent vega mediates family preference for three types of investments, including capital expenditures, research and development (R\&D), and mergers and acquisitions (M\&A), which reflect varying degrees of riskiness. To identify family firms, following Anderson and Reeb (2003a) and Villalonga and Amit (2006), we manually check the proxy statements and other sources when needed. Because the vast majority of the families identified in our sample are in fact founding families, we focus on the founding family, and thus "family" refers to the founding family in the remainder of the paper. We classify our sample firms as active family firms (run by family member CEOs), passive family firms (run by outside professional CEO), and nonfamily firms.

We make several contributions to the literature on family firms. First and foremost, to the best of our knowledge, this paper is the first to analyze the effect of family involvement on investment decisions through CEO pay sensitivities. There have been a number of studies that examine CEO compensation in family firms (Gomez-Mejia et al., 2003) as well as their investment decisions (Anderson et al., 2012), but none of them attempts to consider these two key factors simultaneously. Arguably, the differences observed in the CEO pay structure in family firms are able to explain the differences in investment policy in these firms. Our study fills the gap with better analytical tools that are able to address issues such as endogeneity and/or missing values. Different from Anderson et al. (2012), we assume that investment decisions on capital expenditures and R\&D are made simultaneously, and we consider M\&A as another important choice of investment policy. Our results indicate that CEO compensation is an important and effective governance mechanism that reflects large owner preferences for certain investment behavior. Furthermore, our empirical evidence supports the notion that active family firms design different incentive pay structures that not only reflect their unique preferences, but also further affect their choices of investment policy. 
Second, we refine the typical categorization of "family versus nonfamily" firms in terms of the degree of family ownership. Similar to, for example, Anderson and Reeb (2003a) and Barontini and Caprio (2006), we classify firms into three different types that reflect varying degrees of family involvement both in terms of stock ownership as well as the top management. Indeed, we find that the incentives and the investment patterns appear to differ significantly in active family firms, as opposed to passive and nonfamily firms, a result that could not be captured by the traditional family firm categorization. In fact, adopting this traditional classification approach gives us results similar to Anderson et al. (2012). Hence, a CEO's family affiliation is a valid and important criterion for classifying family firms in a more appropriate manner. This also suggests that replacing a family CEO with an outside professional means not only different behavior from the past but, more importantly, commencement of the transition to a nonfamily firm.

Finally, previous studies from the corporate investment literature usually focus on firm-specific attributes. Several studies explore how managerial incentives influence observable operations and policy choices in addition to the resulting implications (e.g., Guay, 1999; Coles et al., 2006; Hagendorff and Vallascas, 2011; DeYoung, Peng, and Yan, 2013). Our analysis incorporates the aspect of organizational structure by considering ownership (ownership structure) and control (management) at the same time. In line with Anderson et al. (2012), we demonstrate that owner preferences also matter in the choice of corporate investment policy. Because the influence of family ownership is beyond that of typical concentrated ownership (e.g., Mazur and Wu, 2014), research on incentive compensation and corporate investment policy without considering family presence could result in spurious relations and false implications.

The remainder of this paper proceeds as follows: (1) brief literature review followed by formulation of testable hypothesis; (2) description of our data, sample selection, and methodology; (3) presentation of empirical results; (4) discussion and practical implications; and (5) concluding remarks.

\section{Theoretical Foundation}

\section{Corporate Investment Policy in Family Firms}

Family firms have several distinctive features as opposed to nonfamily firms. Family firms are more capable of overcoming the free-rider problem that hinders effective monitoring in diffusely-held firms due to the concentrated ownership of families (Shleifer and Vishny, 1986). Family managers can also create altruistic effects that are beneficial to stakeholders (Schulze, Lubatkin, Dino, and Buchholtz, 2001). In addition, family 
members tend to accumulate wealth through their businesses, so they are less likely to have an opportunistically short time horizon during the decision-making process (e.g., Anderson and Reeb, 2003a; Bartholomeusz and Tanewski, 2006). ${ }^{1}$ This has particularly significant implications for investment choices in family firms. With such long-term commitments and perspectives to ensure firm prosperity (often intertwined with family reputation), coupled with effective monitoring from ownership, families can conceivably avoid the myopic behavior typically observed in nonfamily firms (Shleifer and Vishny, 1986; Stein, 1988; Edmans, 2009). ${ }^{2}$ These arguments formulate the investment horizon hypothesis, indicating that family firms devote more capital to long-term and riskier projects relative to nonfamily firms.

In addition, rational information asymmetry models by, e.g., Holmstrom (1979) and Myers and Majluf (1984), postulate that managers are better informed than the shareholders about the prospects of the firm, and thus must be given some discretion in the decision making process. When managers' and shareholders' interests coincide, managers do not exploit their information advantage at the expense of shareholders, resulting in no misallocation of investments and no reduction in firm value. Following this line of reasoning, family firms should make better investment decisions, especially when these firms are run by families who provide effective monitoring. This would be supported by the standard q-theory of investment (e.g., Brainard and Tobin, 1968; Tobin, 1969), which argues that the determinant of investment is the market valuation of a firm's assets and predicts a positive association between q (market valuation of additional unit of invested capital, or investment productivity) and investment rate. Existing empirical research finds that family firms have significantly higher q as compared to non-family firms (e.g., Villalonga and Amit, 2006).

Nevertheless, the concentrated ownership of families itself gives rise to strong risk aversion. Because their wealth largely depends on firm prosperity, compared with well-diversified shareholders, families have a greater tendency to mitigate firm risk especially by affecting long-term investment choices (Anderson et al., 2012). The uncertainties of long-term investments potentially increase the levels of idiosyncratic risk, which small shareholders can diversify but families cannot. Moreover, greater risk aversion suggests a higher discount rate

\footnotetext{
${ }^{1}$ For instance, a family firm in Japan founded in 578 has gone through 40 generations for building temples. It maintains a long-term horizon and aims to pursue innovative technology. It also values tradition and customer satisfaction, in managing business (http://www.kongogumi.co.jp/idea.html).

${ }^{2}$ Managerial myopia models (e.g., Stein, 1988; Edmans, 2009) explain why managers may choose to focus more on shortterm earnings rather than long-run interests of the firm. These models posit that some investors will never accept weak shortterm earnings, because weak earnings tend to depress stock prices. Therefore, managers may fail to invest in long-term innovative ventures, if such investments mean lower short-term earnings. Firms with atomistic shareholders and the separation of ownership and control, are more likely to have impatient investors that may sell their equity-holdings, once current profits fall short of their expectations. As a result, managers of such firms may be more inclined to make shortsighted investment decisions that maximize short-term profits at the expense of long-term value creation.
} 
that, in effect, shortens investment horizons (Anderson et al., 2012). These arguments develop the risk aversion hypothesis, which predicts fewer long-term and riskier investments in family firms than in nonfamily firms.

Capital expenditures and R\&D expenses are two items that publicly-traded firms are required by regulators to disclose in their accounting statements and proxy for corporate long-term investments. R\&D spending is typically considered riskier, with longer investment horizons relative to capital expenditures. R\&D spending provides more long-term benefits than capital expenditures. For instance, Hall, Jaffe, and Trajtenberg (2005) show that innovative efficiency of R\&D investment displays itself over an extended time path (even beyond 50 years), whereas other classes of expenditures have more immediate effect. R\&D projects are regarded as highrisk investments due to a higher level of information asymmetry and uncertainty regarding investment duration and outcome, among other reasons. Kothari, Laguerre, and Leone (2002), for example, document a significantly higher uncertainty of economic benefits of R\&D spending as compared to other types of expenditure. ${ }^{3}$ Hence, families should be more risk averse to R\&D investments. Anderson et al. (2012) use the 2000 largest U.S. firms from 2003 to 2007 and test the two hypotheses that predict the opposing effects of family firms on investment policy. The authors find a negative relation between family firms and capital allocation to riskier R\&D projects and argue that the risk aversion hypothesis dominates the horizon hypothesis in regard to investment policy in family firms. In contrast, Anderson and Reeb (2003b) demonstrate that family firms diversify less than nonfamily firms as well as maintaining similar levels of debt to them. This evidence does not support the risk aversion hypothesis.

Similar to Anderson and Reeb (2003a) and Villalonga and Amit (2006), in this paper, we identify family firms by two criteria, CEO family affiliation and family ownership, accounting for firm control and ownership structure at the same time. As a result, we have three types of family firms: active family firms (run by family member CEOs), passive family firms (run by outside professional CEOs), and nonfamily firms that represent varying degrees of family involvement within firms, i.e., the highest in active family firms (because families own and control these firms), followed by passive family firms (because families own but do not control these firms), and the lowest in nonfamily firms (as no family presence in these firms), respectively. ${ }^{4}$ Usually passive family firms are considered as a transition phase in which families start loosening their control/ownership. Following the two competing hypotheses proposed by Anderson et al. (2012), risk aversion and investment horizon hypotheses, we formalize our predictions in our first hypothesis that consists of two parts.

\footnotetext{
${ }^{3}$ Kothari et al. (2002) indicate that R\&D is associated with a higher variability of future operating income than capital expenditures by approximately 30\%-70\%.

${ }^{4}$ We adopt a conservative approach to classify family firms in a sense that we do not consider family members working as managers because they would not be able to exert influence as much as CEOs.
} 
Hypothesis 1a: In active family firms (run by family member CEOs), family risk aversion dominates family preference for extended investment horizons, resulting in lower long-term investments (e.g., $R \& D)$ as compared to non-family firms.

Hypothesis 1b: In passive family firms (run by outside professional CEOs), family preference for extended investment horizons dominates family risk aversion, resulting in higher long-term investments (e.g., R\&D) as compared to non-family firms.

\section{CEO Incentive Pay and Corporate Investment Policy}

Option delta and vega are effectively the slope and convexity, respectively, of the CEO pay-performance relation (Jensen and Meckling, 1976). In other words, delta is for the purpose of incentive alignment, which provides a remedy for the agency problem due to separation of ownership and control. Vega is for the risktaking incentive in response to CEO risk aversion because of the undiversifiable wealth concerns, which is similar to diverging risk tolerances between large and small shareholders discussed in the previous section.

On the theoretical front, it is commonly argued that convex payoffs of stock options make risk more valuable to managers and thus should be able to mitigate managerial risk aversion and provide incentives for them to undertake risky investments. However, this depends on the managerial utility function. Guay (1999) and Ross (2004) indicate that the concavity of the utility function of a risk-averse manager can significantly offset the incentives from the convexity of pay structure. In addition, models developed by Haugen and Senbet (1981), and Smith and Stulz (1985) argue that firms should manage the sensitivity of managers' wealth to the volatility (riskiness) of firm's equity. This is because managers should be rewarded for risk-increasing positive NPV investment projects that the firm desires to undertake. Ju, Leland, and Senbet (2002) illustrate that a call option contract can induce not only too much but also too little risk-taking behavior. Moneyness of options can have different impacts on risk-taking behavior: Out-of-the-money or at-the-money options induce better risk-taking behavior than in-the-money options (Lewellen, 2003; Parrino, Poteshman, and Weisbach, 2005). Empirically, several studies link managerial stock and/or option holdings to financial strategies as well as corporate focus, with mixed results. ${ }^{5}$ The evidence on firm risk is more consistent: Return volatility is positively associated with the pay-risk sensitivity (Guay, 1999; Cohen, Hall, and Viceira, 2000). This also implies that firms actively manage risk-taking incentives.

\footnotetext{
${ }^{5}$ See, e.g., Berger, Ofek, and Yermack (1997), Denis, Denis, and Sarin (1997), DeYoung et al. (2013), Mehran (1995), and Rogers (2002).
} 
Corporate investments are crucial to firm valuation and performance. Different investment types have varying degrees of outcome uncertainty and horizon. The extant literature indicates that vega affects managerial decisions on investment policy. Coles et al. (2006) find that vega increases R\&D, diversification, and leverage and decreases capital expenditures after controlling for delta and the feedback effects of firm policy and risk on managerial compensation. Similarly, Nam, Ottoo, and Thornton Jr. (2003) also find that vega is related to more leverage and higher levels of R\&D. Hagendorff and Vallascas (2011) indicate that vega increases risk-inducing mergers in the banking industry after controlling for delta and other firm-specific and governance attributes. DeYoung et al. (2013) further demonstrate that vega increases risk-taking business policies at large U.S. commercial banks and that bank boards respond to higher-than-average levels of risk by moderating CEO risktaking incentives.

Despite the clear effect of vega on corporate investments, the relation between delta and risk-taking is ambiguous. Theoretically, delta motivates managerial efforts to identify positive NPV projects that can be risky. On the other hand, such (a high level of) riskiness can expose managers to a level that exacerbates risk aversion (Hagendorff and Vallascas, 2011), especially when high-delta compensation over time makes managerial wealth closely linked to the firm (DeYoung et al., 2013). These opposing predictions might explain the inconsistent findings in empirical studies (e.g., Datta, Iskandar-Datta, and Raman, 2001; Coles et al., 2006).

\section{CEO Incentive Pay in Family Firms}

The bulk of managerial incentives are generated by executive stock options and option-like payouts, as well as by the ownership of firm’s equity-holdings (e.g., Jensen and Murphy, 1990; Hall and Liebman, 1998). Stock options are a large component of executive compensation package. Chhaochharia and Grinstein (2009) report that equity-based pay constitutes, on average, over 50 percent of a typical executive pay package. As for the ownership of firm's equity, it can be accumulated by executives over the length of their tenures at the firm. Alternatively, in family firms equity stakes are typically retained by a founder(s) at the initial public offering (IPO) and then plausibly pass on to the descendant(s). Helwege, Pirinsky, and Stulz (2007) report that insiders keep on average $38 \%$ of firm's ownership within the first year of the IPO, and $24 \%$ within the first ten years after going public. Because of large equity ownership as typically held by families, their exposure to firm risk is high: wealth of families depends heavily on firm performance.

To the best of our knowledge, there is still little research that examines the relation between family firms and CEO compensation. Gomez-Mejia et al. (2003) first investigate the determinants of executive compensation in 
publicly-traded family firms in the U.S., and they find that family CEOs of family-controlled firms receive lower total income than outside professional CEOs, the income difference increasing with family ownership concentration. In addition, their pay tends to be more insulated from systematic risk, which is further moderated by the presence of institutional investors and $R \& D$ intensity. They argue that institutional investors might reduce equity-based income to avoid conservative decisions in an already risk-averse family business context. Mazur and Wu (2014) study small publicly-traded firms in the U.S. and find that cash and total compensation seem unaffected by family presence. Delta is highest in firms controlled and run by families.

Together, these studies imply that family firms should have different investment policies affected by their incentive pay in place. These studies also suggest that managerial incentives represent a channel through which firms influence managers' investment behavior. As noted before, our primary variable of interest is stock option vega, and we use delta as a control variable in the analysis because of its ambiguous effect on risk taking. In light of above discussion, we formulate our next hypothesis as follows,

Hypothesis 2: CEO incentive pay manifests family preferences and thus mediates the relations between families and investment choices, such that CEO stock option vega is lower in active family firms and higher in passive family firms.

Additionally, we expect that the aforementioned predictions should be affected by the riskiness of a firm. Specifically, if family preference for low risk prevails, the negative relation between active family firms and risky investments should be more pronounced in high-risk firms. Alternatively, if family preference for investment horizons prevails, the positive relation between passive family firms and risky investments should not be significantly different between high- and low-risk firms. If anything, such a relation might be more pronounced in low-risk firms (due to the increased risk-aversion preference in high-risk firms). The above predictions can be formulated as follows,

Hypothesis 3a: In active family firms, family risk aversion dominates family preference for extended investment horizons, resulting in lower long-term investments (e.g., R\&D) as compared to non-family firms. Such a prediction is expected to be more prominent in high-risk firms.

Hypothesis 3b: In passive family firms, family preference for extended investment horizons dominates family risk aversion, resulting in higher long-term investments (e.g., R\&D) as compared to non-family firms. Such a prediction is expected not to be affected by firm risk.

\section{Methods}




\section{Data and Sample}

Following Mazur and Wu (2014), we form our sample from companies in the S\&P600 SmallCap Index between 2001 and 2005, the most recent period with no major disruptive economic events. Our analysis focuses on small companies to avoid the aggregation bias, i.e., the aggregation of asynchronous actions across business units can smooth firm-level investment, which potentially arises with firm size (Whited, 2006). In addition, other than the economic significance, family influence is more prominent and effective in small firms compared with their more established counterparts. Our sample starts in 2001, so that we can avoid market-based performance measures that were significantly inflated in 2000 when the dot-com bubble reached its climax. Our sample ends in 2005 because the U.S. Securities and Exchange Commission introduced new disclosure rules on executive pay in 2006; thus, the most recent compensation data are not fully compatible with the pre-2006 format. Therefore, our sample period is relatively free of major financial or regulatory events as well. We exclude firms in this index that did not survive the full sample period, ensuring that our sample firms remain relatively small. Similar to Anderson et al. (2012), we further exclude utility (SIC codes 1311, 4911 to 4991) and financial firms (SIC codes 6020 to 6799) because these firms are typically under government regulations that might affect their investment policies and ownership structures. We also exclude spin-off firms. These sample selection criteria result in 1,756 firm-year observations that represent 362 unique firms. We match our final sample with the available accounting data in Compustat, compensation data in ExecuComp, ${ }^{6}$ corporate governance data in RiskMetrics, mergers and acquisitions data in SDC (Securities Data Company), stock price data in CRSP (The Center for Research in Security Prices), and patent data in Bronwyn Hall’s online database.

To identify family firms, we manually check proxy statements for each company along with other sources when needed, ${ }^{7}$ providing us with the following information: identity, ownership, tenure, and biographies of founder(s), board members, blockholders, and the top-five managers when such information is available. We classify family firms based on two dimensions, namely, family affiliation of board members (control) and of CEOs (management). Following Anderson and Reeb (2003a) and Villalonga and Amit (2006), we classify a firm with family control as long as one of the following two criteria is met: (1) The founder or a descendant of the founder sits on the board and/or is a blockholder and (2) at least two board members are related either by

\footnotetext{
${ }^{6}$ We rely on the CEO identification in ExecuComp (item CEOANN) to form the sample. Note that, in cases of CEO turnover in a given year, the ExecuComp typically identifies the departing CEO as the annual CEO. However, the proxy statement reports the replacing one as the company CEO.

${ }^{7}$ Such as, Linkedin, Zoominfo, the website of the company, and etc.
} 
blood or marriage. ${ }^{8}$ Overall, $48.46 \%$ of the sample observations are affiliated with founding families, $46.41 \%$ are managed and owned by outsiders, and 5.13\% are affiliated with non-founding families. ${ }^{9}$ Following, e.g., Miller, Le Breton-Miller, Lester, and Cannella (2007), we include non-founding family firms among familycontrolled firms in our sample. ${ }^{10}$ Among our 1,756 firm-year observations, 546 (31.09\%) are of active family firms, 395 (22.49\%) are of passive family firms, and 815 (46.41\%) are of nonfamily firms.

\section{Measures}

Incentive Pay Our main estimates for incentive pay are two CEO option portfolio sensitivities. We follow Core and Guay (2002) and Brockman et al. (2010) to calculate two sensitivity measures. First, the CEO portfolio price sensitivity (PRCSEN) is defined as the change in the value of the CEO stock holding and option portfolio in response to a $1 \%$ change in the firm stock price. Second, the CEO portfolio volatility sensitivity (VOLSEN) is defined as the change in the value of the CEO option portfolio in response to a $1 \%$ change in stock return volatility. Partial derivatives of the option price with respect to stock price (delta $\delta$ ) and stock return volatility (vega $v$ ) are based on the Black and Scholes (1973) for valuing European call options, adjusted for dividend payouts by Merton (1976). ${ }^{11}$ This approximation procedure has been commonly adopted in prior works, e.g., Knopf , Nam Jr., and Thornton (2002), Rajgopal and Shevlin (2002), and Coles et al. (2006).

Long-term Investments and M\&A Activities We use capital expenditures, R\&D expenses, and M\&A activities to proxy for long-term corporate investments. Typically, capital expenditures and R\&D are considered sources for internal growth while M\&A deals are viewed as sources for external growth. This motivates us to separate the analysis on M\&A activities from that on capital expenditures and R\&D spending. With regard to accounting-wise long-term investments, we collect data from the Compustat database. Capital expenditures and R\&D expenses are measured as a fraction of total assets, which gives better comparison over time and across firms. Many prior studies note that many firms at times fail to report R\&D expenses in their accounting statements. ${ }^{12}$ One common method in the empirical research in business is to replace these missing values for

\footnotetext{
${ }^{8}$ Follow Gomez-Mejia et al. (2003), we consider father, mother, sister, brother, son, daughter, spouse, in-laws, aunt, uncle, niece, nephew, and cousin.

${ }^{9}$ The percentage of family firms in our sample is higher than that (38.13\%) in Anderson et al. (2012). This can be due to different sample construction and different definition of family firms. In particular, family presence is more common in small firms than in their more established counterparts. But we believe that it does not seriously affect the generality of our results as we focus on the comparison between family and non-family firms.

${ }^{10}$ In some cases, we cannot obtain founder information. It is also likely that we lose track of founding family members. Thus, we underestimate the true proportion of family firms in the sample. This would potentially work against our testing hypotheses.

${ }^{11}$ See, e.g., Brockman et al. (2010) for a detailed description of the computation of the option delta and vega.

${ }^{12}$ For instance, about $42 \%$ of public firms in Kob and Reeb (2014), 33.17\% in Anderson et al. (2012), or 35.65\% in our sample.
} 
R\&D with zeros. We adopt this assumption in our main analysis and employ alternative econometric models to address this issue in our sensitivity analyses section.

In addition, we match our sample observations with M\&A data from the SDC US Mergers and Acquisitions Database. We measure M\&A activity by two proxies, the number and the total transaction value of the M\&A deals made by a firm in a given year. Note that SDC does not report transaction values for a substantial amount of M\&A deals (approximately 55\% in the deals made by our sample firms), especially for those in which the target firm is a private firm or a subsidiary of a public firm, and some small deals could go unrecorded in SDC (e.g., Celikyurt, Sevilir, and Shivdasani, 2010). A common method employed in the literature is to assume these missing values to be zero, which could seriously underestimate the actual transaction values. To address this issue, we use the number of deals as an alternative measure for analysis.

Control Variables Prior work evinces more interest in the resulting effects of pay incentives than the incentives themselves. Generally, these incentives are regarded as exogenous in the analysis. Nevertheless, a number of studies view the structure of pay incentives as a choice and thus of research interest in its own right. Earlier, delta attracted strong academic interest (e.g., Bizjak, Brickley, and Coles, 1993; Core and Guay, 1999). More recent research has shifted the interest to vega itself, or vega and delta simultaneously (e.g., Coles et al., 2006; DeYoung et al., 2013). The evidence suggests that, on the one hand, vega is positively related to sales, marketto-book, firm risk, and CEO cash compensation (Coles et al., 2006). On the other hand, delta is positively associated with market-to-book, CEO tenure, and firm risk (Core and Guay, 2002; Coles et al, 2006; DeYoung et al., 2013) despite the evidence with regard to the relation between firm risk and delta being mixed (Aggarwal and Samwick, 1999). These findings together indicate that delta and vega are determined simultaneously by several common factors. We use firm size, Tobin’s Q, CEO age, CEO cash compensation, and CEO duality (as a proxy for corporate governance) as five control variables in our analysis.

There is a tremendous amount of literature on the determinants of corporate investments. Because we aim to examine how family firms affect their investment choices, similar to Anderson et al. (2012), we include two sets of control variables capturing asset and financing attributes that potentially influence investment policy. First, we use the natural logarithm of total sales to control for firm size. We use Tobin's Q, defined as the market value of total assets scaled by the book value of total assets, to control for growth opportunity. We also control for life cycle by using the natural logarithm of firm age, which is the difference between the founding year and the current year. We collect data on the founding year from various sources such as FundingUniverse.com, proxy statements, and company websites. 
Furthermore, we use four measures to account for the impact of financing constraints. First, we use cash holdings over total assets to measure a firm's liquidity or the ability to provide internal funding for investments. Second, we use long-term debt over total assets to measure a firm's leverage ratio, which indicates its funding capacity, both internally and externally. Third, we use total property, plant and equipment over total assets to measure asset tangibility, which represents a firm's ability to obtain external financing because it reduces contracting problems (Almeida and Campello, 2007). Finally, we use cash dividends over total assets to control for the dividend payout. On the one hand, firms with financial constraints have significantly lower dividend payout ratios. On the other hand, all else equal, firms allocating more capital to investments have fewer financial resources for dividend payouts. Thus, the relation between investment expenses and dividend payouts is not clear, depending on whether the financial constraint or the substitution effect dominates. We also include dummy variables for two types of family firms and for industry and year fixed effects in our regression analysis. Table A.1 provides a detailed description of the variable definitions and data sources in this paper.

[Please insert Table A.1 here]

\section{Empirical Specification}

To estimate the impact that families have on corporate investment decisions as a consequence of their CEO pay incentives, we specify the following structural model:

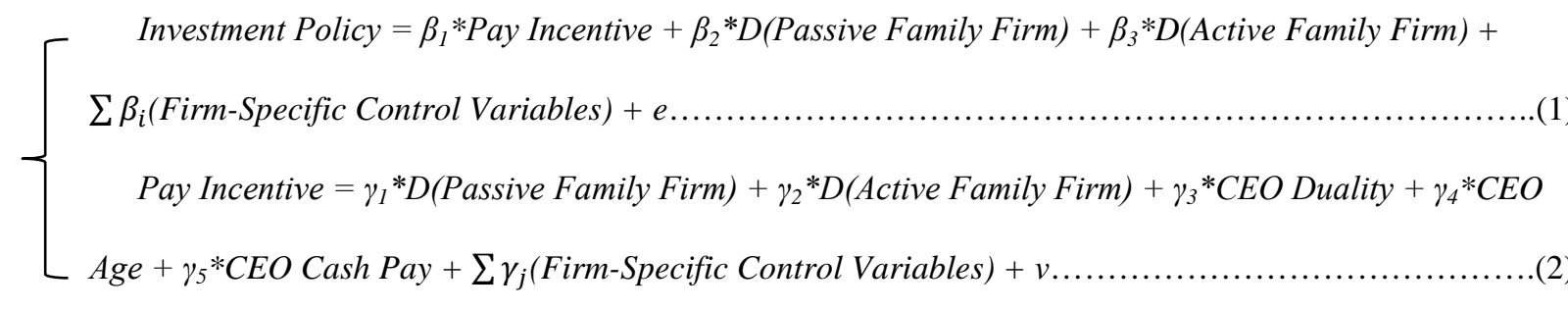

where $\mathrm{D}(\mathrm{x})$ is a dummy variable for variable $\mathrm{x}$. Note that $\operatorname{cov}(\mathrm{e}, \mathrm{v})$ is allowed to be nonzero, meaning that we allow for the possibility that the error terms are correlated across (1) and (2).

In effect, there are two equations in our model. The first equation (1) is the investment policy equation and explains how a certain investment choice is determined. The second equation (2) is the pay incentive equation and describes the determinants of pay incentives. By substituting (2) into (1), we can obtain the reduced form equation for the model as follows:

Investment Policy $=\left(\beta_{1} \gamma_{1}+\beta_{2}\right) * D($ Passive Family Firm $)+\left(\beta_{1} \gamma_{2}+\beta_{3}\right) * D($ Active Family Firm $)+\beta_{1} \gamma_{3} * C E O$
Duality $+\beta_{1} \gamma_{4} *$ CEO Age $+\beta_{1} \gamma_{5} *$ CEO Cash Pay $+\sum\left(\beta_{1} \gamma_{j}+\beta_{i}\right)($ Firm-Specific Control Variables $)+\varepsilon \ldots . . . . . .(3)$ 
It is clear from the reduced form equation (3) that family firm variables can affect investment policy in two ways. The first is the direct effect of a particular family firm variable and is captured by $\beta_{2}$ or $\beta_{3}$, and the second is the indirect effect of the same variable via the pay incentive equation and is captured by $\beta_{1}{ }^{*} \gamma_{1}$ or $\beta_{1}{ }^{*} \gamma_{2}$. The latter are also called the mediating effects, i.e., the effects that mediate the total effects (see, e.g., Acock, 2013). Given a certain type of pay incentive, the total effect of family presence on a certain investment policy is $\beta_{1}{ }^{*} \gamma_{1}+\beta_{2}$ for passive family firms and $\beta_{1}{ }^{*} \gamma_{2}+\beta_{3}$ for active family firms. To estimate the model, the maximum likelihood (ML) estimation method is used. As long as the model is correctly specified, ML estimates are consistent and efficient. Noted for its flexibility (and potentially better model fit), it can give estimates similar to seemingly unrelated regression or simultaneous equation analysis, in addition to other desirable features (Tomarken and Waller, 2005). ${ }^{13}$

The path diagram in our structural model is displayed in Figure A.1. A path is typically displayed as an arrow, drawn from one variable to another, and establishes the relation (causality) between these two variables. As exhibited in Figure A.1, there are four sets of linear regressions in the model (i.e., four endogenous variables that are jointly determined). Two are related to investment choices (i.e., capital expenditures and R\&D spending; M\&A number and value); in addition, two are for pay incentives (i.e., delta and vega) that are set and designed to further affect investment choices as well. We also specify the variables to be correlated (based on the correlations between variables as exhibited in Table A.3) and include industry and year dummy variables in the two linear regressions of investment choices (not shown in the model path diagram for simplification). Standard deviations are clustered on the firm level.

[Please insert Figure A.1 here]

\section{Results}

\section{Descriptive Statistics}

Table A.1 also provides descriptive statistics for the principal variables of interest in our sample. On the whole, the mean (median) level of delta is $\$ 299,190(\$ 132,140)$, and the level of vega is $\$ 49,630(\$ 30,800)$. These numbers are nearly half of those reported in Coles et al. (2006) and Hagendorff and Vallascas (2011). A possible reason for this is that our sample firms are relatively small, and small firms tend to have smaller

\footnotetext{
${ }^{13}$ We use sem in Stata to generate estimates and test results. Specifically, we adopt the maximum-likelihood-with-missingvalues approach for estimation in which missing values are assumed to be missing at random. When compared to simultaneous equation analysis (reg3 in Stata), in addition to some desirable results for the purpose of our study, SEM can easily produce robust/clustered variances and incorporate correlated variables.
} 
compensation relative to larger establishments. ${ }^{14}$ In addition, the mean (median) level of CEO cash compensation is $\$ 870,040$ ( $\$ 680,550)$, approximately $75 \%$ of the levels in Coles et al. (2006). Our sample has a mean (median) ownership of $8.23 \%$ (2.5\%), which is reduced to 3.5\% (0.68\%) once stock ownership alone is considered. The average CEO is 55 years old.

Moreover, our sample includes firms with annual total sales of 805.4 million on average and with a median of 503.41 million. The return on assets is approximately 8\%, and the Q ratio is 1.79 as a whole. In general, firms hold cash (12\%) and not much debt (16\%). An average firm allocates $25 \%$ and $1 \%$ of its assets to tangible assets and cash dividends, respectively. The mean firm age is 47 , while some firms' roots can be traced back to the late $18^{\text {th }}$ century. On average, the value of capital expenditures and that of the R\&D expenses are $5 \%$ and $3 \%$ of the book value of assets, respectively. Firms spend 3\% of market capitalization and make 0.59 M\&A deals each year. There are 8 members on the board of directors, and 52\% of firm CEOs are the chairman of the board.

Table A.2 presents the mean and median tests of the differences in selected CEO- and firm-specific characteristics between three types of family firms. Generally speaking, delta is highest in active family firms $(\$ 611,080)$, while vega is highest $(\$ 54,790)$ in nonfamily firms. Other than pay incentives, we find that CEOs in active family firms are older (57) and own much more in equity stakes $(20.09 \%$ and $9.01 \%$ excluding stock options). Note that the level of CEO cash compensation is similar across firms with varying degrees of family involvement (although the median level is lower in active family firms). With regard to firm-specific characteristics, there is no significant difference among the three firm types in terms of operating performance and firm size. However, firm age indicates that these three types of family firms represent different stages in the life cycle, i.e., family firms tend to be younger and smaller, while nonfamily firms tend to be older and larger. Hence, it is not surprising that active family firms have the highest firm risk (and idiosyncratic risk). This also suggests that the status of passive family firms is transitory. Overall, family firms have higher growth opportunities, hold more cash, issue less debt, and have lower tangible assets. Passive family firms pay the highest cash dividends.

[Please insert Table A.2 here]

The level of capital expenditures is similar irrespective of family presence. Passive family firms have higher R\&D expenses and are more prone to M\&A deal making. This can be a result of high risk aversion in active family firms and the lack of investment opportunity in nonfamily firms. Moreover, active family firms tend to

\footnotetext{
${ }^{14}$ The levels of vega in our sample are similar to those reported in Low (2009) whereas our numbers in terms of both delta and vega are significantly higher than those reported in Brockman et al. (2010).
} 
be less entrenched, with fewer anti-takeover provisions and a smaller board of directors, which is generally viewed as being more effective. However, their CEOs are most likely to serve as chairman of the board. On the contrary, CEOs in passive family firms are least likely to serve as the chairman. Finally, the test results indicate that although active family firms file fewer patents, they generate a similar amount of citations compared to the other two firm types.

Table A.3 displays the correlations among the key variables of interest. The correlation between capital expenditures and R\&D is -0.09 (p-value $=0.0001$ ). So, firms investing more in capital expenditure have lower R\&D expenses. This suggests that, consistent with related literature, these two investments are arguably substitutes, but only to a lesser extent (because economically the magnitude of this correlation is relatively low). Indeed, our regression results indicate that they do not seem to replace each other. In addition, the correlation between M\&A number and value is 0.69 (p-value $=0.0000$ ). Hence, firms that are more active in $M \& A$ activities tend to engage in larger deals. The correlation between delta and vega is 0.35 (p-value $=0.0000$ ). We incorporate such a correlated feature into our model, as described in the previous section.

[Please insert Table A.3 here]

\section{Primary Findings}

Capital Expenditures and $\boldsymbol{R} \& \boldsymbol{D}$ Expenses In this section, we investigate the extent to which incentives from CEO compensation packages, in particular the risk-taking incentive vega, mediates the effect of family preferences on corporate investment policy (H1a, H1b, and H2). Specifically, we first consider capital expenditures and R\&D expenses together as investment policy. The latter is typically viewed as being riskier with longer investment horizons compared to the former. As hypothesized, we expect that active family firms have lower vega and allocate less capital to R\&D and more to capital expenditures than do nonfamily firms. A lower level of vega indicates a stronger risk aversion preference of families and thus provides a mediating effect on that preference. We expect that passive family firms, on the contrary, have higher vega and allocate more capital to R\&D and less to capital expenditures than do nonfamily firms. A higher level of vega indicates a stronger long-horizon preference of families and thus provides a mediating effect on that preference. Table A.4 reports the estimates of direct effects, indirect effects, and total effects for Models 1 and 2, for which Model 1 uses a dummy variable called family to capture whether a firm is a family firm and Model 2 uses two dummy variables called active family and passive family to capture whether a family firm is run by a family CEO.

[Please insert Table A.4 here] 
As displayed in Table A.4, family firms, especially active family firms, devote less capital to R\&D projects compared to nonfamily firms. In addition, the results of Model 2 reveal that approximately one-third (-0.0032/0.01) of the total effect $(-1 \%)$ is mediated by the incentive pay (the indirect effect of $-0.32 \%) .{ }^{15}$ These findings provide evidence that incentive pay is an important channel whereby families manifest their preference for lower risk and greatly mediate the effect of such a preference for risky investment choices. Note that the coefficient of the passive family dummy is not statistically significant (the total effect), indicating that there is no significant difference in R\&D spending between passive family firms and nonfamily firms. That being said, this result also indicates that passive family firms engage in R\&D more when compared to active family firms. ${ }^{16}$ Hence, the family preference for risk aversion seems to give way to a preference for horizons once a family CEO is replaced by an outsider. Note that the effect of family firms is not statistically significant, arguably due to opposing predictions of active and passive family firms. In contrast to many prior studies, family presence has no impact on capital expenditures. After taking into account the control variables for delta and vega, as exhibited in the lower part of Table A.4, vega is lowest in active family firms that have the highest delta. Vega in passive family firms is lower than nonfamily firms (but higher than active family firms). This is in line with the aforementioned interpretation that the risk aversion hypothesis prevails in firms controlled and operated by families, but such a preference might be reduced and the family preference for horizons enhances when family CEOs are replaced by outside professionals.

Consistent with the literature, vega induces managerial decisions to invest in risky R\&D projects. Higher delta results in lower R\&D. In terms of the total effect, Tobin’s Q (+) and firm age (-), which capture investment opportunities, have the same signs for both types of investments. Firm size decreases and cash holdings increase R\&D. Leverage has an adverse effect on capital expenditures but not on R\&D. Cash dividends lower both capital expenditures and R\&D, which suggests the substitution effect outweighs the financial constraint effect. Asset tangibility is positively associated with capital expenditures, whereas its relation with $R \& D$ is negative. Overall, we do not find evidence that families prefer to invest in capital expenditures, suggesting that families might not consider capital expenditures a low-risk type of investment that can substitute for risky $R \& D$ investments. Additionally, capital expenditures and R\&D share common determinants, which do not always

\footnotetext{
${ }^{15}$ The direct and indirect effects of active family firms on R\&D spending are not statistically significant from zero at the $10 \%$ level, although the total effect is. Econometrically, neither the individual component has an effect that is significantly different from zero, but the sum is far enough away from zero. Alternatively, we use the bootstrapping approach and obtain bootstrapped standard errors. Both direct and indirect effects are statistically significant under this approach.

${ }^{16}$ When using two binary variables for passive family and nonfamily firms, the estimated coefficient of the binary variable for passive family firms is positive and statistically significant. The results are not reported and are available upon request.
} 
have opposite predictions. Hence, these two types of investments do not necessarily represent alternative choices.

M\&A Activities In this section, we focus on M\&A activities by examining the number and the value of M\&A deals. Table A.5 follows the setup of Table A.4 and reports the coefficient estimates. At first glance, as indicated in Models 1 and 2, we find that M\&A activities are not affected by family presence as a whole. Again, similar to the previous section, active family firms and passive family firms seem to behave differently in M\&A deal making as well. Specifically, passive family firms are more active in M\&A and conduct more deals relative to nonfamily firms (and active family firms because active family firms and nonfamily firms exhibit similar levels of M\&A activities). Interestingly, the total effect of passive family firms on the M\&A number coincides substantially with the direct effect and is not greatly mediated by incentive pay (only $-0.01 / 0.069$ ). If anything, this suggests that such incentive pay mitigates, rather than manifests, the family preference for horizons in passive family firms. Similarly, these findings are consistent with the aforementioned notion that the family risk-aversion preference seems to give way to horizon preference once a family CEO is replaced by an outsider. There is no significant difference in M\&A deal value among the three firm types. Vega increases both the number as well as the value of M\&A deals. Delta seems irrelevant in the decision to engage in M\&A deals.

[Please insert Table A.5 here]

Moreover, in regard to firm-specific attributes, an old firm conducts fewer and smaller M\&A deals. With respect to financial constraints, a firm with lower cash holdings, tangible assets, and cash dividends as well as more leverage has a greater tendency to make (larger) M\&A deals. In other words, M\&A is associated with less availability of (both internal and external sources of) funding, which is inconsistent with the financial constraint argument. This therefore suggests that M\&A investments are not restricted by funding availability. Because internal funds are scarce, many of these deals are likely to be financed by external funding. Tobin's $Q$ is not related to M\&A, which might suggest that these deals are not made to take advantage of (internal) growth opportunities. Note that the number and the value of M\&A deals share common (if not identical) determinants that have the same predictions (in terms of signs). This provides supporting evidence that the decision to conduct a deal and the evaluation of the deal are determined jointly.

Overall, as shown in Tables A.4 and A.5, using two family dummies in the regressions rather than adopting the conventional two-type categorization would increase the model explanatory power. 
Pay Incentives and Investment Choices in Family Firms To further examine the relations between family CEO incentive pay and investment choices, we produce several figures that help us better understand the family preferences. Figure A.2 displays three scatter plots of vega and delta in three types of family firms. Figure A.3 (4) displays three contour plots of vega, delta, and R\&D (the M\&A number) for these firms. ${ }^{17}$ Figure A.2 first shows that the joint distribution of vega and delta is more scattered (clustered) in active (passive) family firms relative to nonfamily firms. Given a certain level of delta (particularly a higher delta), vega tends to be lower in active family firms, which can be due to the risk aversion preference. Vega does not exhibit such a tendency in passive family firms, which supports the horizon preference. In Figure A.3, there are a few small areas indicating high R\&D spending (in colors red and brown) in active family firms, and these "hot zones" appear to be larger in passive family firms. The same patterns hold for M\&A deal making, as demonstrated in Figure A.4. Interestingly, in passive family firms, a higher deal number seems to be associated with a higher vega given a certain level of delta. Overall, these figures provide additional evidence supporting family preference for lower risk in active family firms and family preference for horizons in passive family firms. Moreover, relative to active family firms, vega seems less "pressed” in passive family firms motivated to undertake risk-taking projects.

[Please insert Figures A.2, A.3, and A.4 here]

Investment Choices and Firm Risk Profile In the spirit of Anderson et al. (2012), we conduct separate tests based on the riskiness of firms. If the risk aversion hypothesis dominates, we should observe the negative relation between family presence and risky investments more pronounced in firms with higher risk $(H 3 a)$. Alternatively, if the investment horizon hypothesis prevails, families should invest more in risky projects, regardless of risk $(\mathrm{H} 3 \mathrm{~b})$. The subgroup analysis in this section provides test results for these hypotheses. We use the standard deviation of stock returns for the past 60 months as a proxy for underlying firm risk. In addition, similar to DeYoung et al. (2013), we estimate market risk and idiosyncratic risk from the Fama-French threefactor model. We expect that when firms are separated by firm risk, the results would be driven by idiosyncratic risk because concentrated shareholdings make families undiversified investors who thus have more exposure to idiosyncratic risk.

We report the direct/indirect/total effects for the variables of primary interest only in Tables A.6 and A.7, which replicate the model specifications of Tables A.4 and A.5, respectively. In each table, Panel A displays

\footnotetext{
${ }^{17}$ These contour plots are produced using the thin-plate-spline interpolation method in Stata.
} 
separate regression results based on (median) firm risk. Similarly, Panel B (C) displays results based on market (idiosyncratic) risk. On the one hand, the results support the risk aversion hypothesis for an average firm with a high degree of family involvement. Active family firms prefer fewer risky R\&D projects especially when they face a riskier business environment. This holds whether the risk is firm risk, market risk, or idiosyncratic risk. This therefore suggests that families aim to mitigate any type of risk that their firms have. On the other hand, passive family firms devote more resources to R\&D compared to active family firms but have a similar level of $R \& D$ as nonfamily firms when facing a riskier environment (interestingly, the exception is high idiosyncratic risk). When facing a lower market risk, these firms have more R\&D than the other two types of firms. These findings are consistent with the investment horizon hypothesis.

[Please insert Table A.6 here]

In general, vega increases $R \& D$ investments in low-risk firms and decreases capital expenditures in firms with higher idiosyncratic risk. Hence, these results indicate that incentive pay induces (the proper types of) investments contingent on the firm's existing level of riskiness. Furthermore, we find that the results are similar to the primary results in Table A.4. Particularly for active family firms, their choices of delta and vega seem to be irrespective of the riskiness of firms. Nonetheless, in passive family firms, delta is lowest in the face of lower market or idiosyncratic risk. In addition, vega is no longer lower than nonfamily firms in the face of a riskier environment. It is possible that in firms with higher risks, vega does not induce risky projects, and thus the need for a low vega in firms with a family preference for horizons (i.e., passive family firms) is reduced. Hence, vega in such firms is both less negative economically and less significant statistically relative to their low-risk counterparts. Note that there are more active family firms in the subgroup of high risk, which potentially aggravates their preference for lower risks. ${ }^{18}$

In Table A.7, we find that the primary results regarding the M\&A activities of families in Table A.5 are driven by low-risk firms. Specifically, passive family firms are more active in M\&A deal making in firms with low firm risk or idiosyncratic risk. Interestingly, delta increases the deal value in firms with low firm risk or idiosyncratic risk, whereas vega induces deal activities in firms with high firm risk or idiosyncratic risk. Overall, M\&A models in the low-risk subgroup have higher explanatory power. Note that the explanatory power in these models is generally higher relative to their pooled model in Table A.5.

[Please insert Table A.7 here]

\footnotetext{
${ }^{18}$ For instance, in our sample, almost $60 \%$ of the active family firms are classified as high firm-risk firms, whereas $46 \%$ and $45 \%$ of the passive and nonfamily firms, respectively, are classified as high firm-risk firms.
} 


\section{Sensitivity Analyses}

In this section, we conduct additional analysis to test the robustness of our primary findings. First, we use patent data to address issues concerning missing R\&D values. In addition, we use alternative estimation models to address potential sample selection issues regarding missing $R \& D$ values and endogeneity issues regarding family involvement.

R\&D Outcomes and Patents Filed/Cited Our primary results indicate that CEO incentive pay mediates the relations between family involvement and investment choices. More specifically, family CEO incentive pay manifests the family preference for lower risk in active family firms that have lower R\&D spending. We also find evidence for family preference for longer investment horizons in passive family firms that increase investments in $R \& D$ and $M \& A$ deals. In this section, we investigate the relations between families and $R \& D$ outcomes.

The main reason that we examine $R \& D$ outcomes is because a significant amount of our sample observations have missing R\&D values. As mentioned previously, a common approach adopted in the business literature is to assign zero values to these missing values. However, there is growing evidence suggesting that it is a firm's choice not to report $R \& D$ expenses. As a result, using this approach in the analysis might underestimate the true R\&D efforts for these firms. The existing literature argues that R\&D expenses serve as an input that feeds the innovative process in which patents are one potential output. Arguably, the number of patents would proxy for R\&D outcomes. However, it is not necessarily a good proxy for innovative efforts because of the large variance in value and the lack of incorporating influence of the individual patents (Hall et al., 2005). Hence, the number of patent citations is considered a better proxy for the value of R\&D efforts. We use both proxies in our analysis.

Following Anderson et al. (2012), we collect patent and patent citation data from Bronwyn Hall's database. ${ }^{19}$ We calculate the number of citations for each patent and the number of patents filed for each firm-year observation (and thus the sum of citations generated from these patents) based on the Compustat firm-level identification number (i.e., permno). We then match these two constructs to our sample. Table A.8 Panel A provides statistics for patents filed and citations for three subgroups, those with missing R\&D, with zero R\&D, and with positive R\&D. We observe that both patent number and patent citation seem to be higher in the missing $R \& D$ group than in the zero $R \& D$ group. This suggests that assuming no $R \& D$ in firms that do not

\footnotetext{
${ }^{19}$ See Kogan, Papanikolaou, Seru, and Stoffman (2012) for a detailed description of the data matching procedure, which is an ongoing project.
} 
report $R \& D$ expenses underestimates the true value of their $R \& D$ efforts. Nevertheless, we notice that these numbers are much lower than those in the positive R\&D group. Therefore, replacing missing values with zeros might not seriously bias our results.

[Please insert Table A.8 here]

Moreover, from Table A.8 Panel B, we find that the mix of family firms seems similar across different R\&D subgroups. Thus, it appears that family presence does not play a role in R\&D reporting practices. We find that in the positive R\&D group, passive family firms have the highest number of patents filed as well as of patent citations, which lends support for the horizon hypothesis. Interestingly, active family firms have the fewest patents filed, but they have slightly more citations (or at least a similar number of citations) relative to nonfamily firms. This suggests that despite a family preference for lower risk that leads to fewer patents, these patents filed by active family firms are more influential. In the missing $\mathrm{R} \& \mathrm{D}$ group, nonfamily firms have the greatest active patent activity compared to the other two firm types. Consequently, these firms would be more prone to biases resulting from assigning zeros to missing values. Finally, we use these two constructs as dependent variables and conduct similar structural analysis. As exhibited in Table A.8 Panel C, there is no strong evidence for either hypothesis after controlling for a set of likely determinants.

Alternative Estimation Models In this section, we aim to address issues arising from missing R\&D values by employing alternative econometric models. In the spirit of Anderson et al. (2012), we first use a Tobit model that addresses censored data. Because the missing values for R\&D are assigned the value zero, there is a large cluster of zero observations in our sample. Tobit regressions are appropriate for empirical analysis with such censored data. Nevertheless, unreported R\&D values can the result of firm choices. The level of R\&D and the likelihood of the data being reported are likely jointly determined. That is, the occurrence of these missing values is endogenous (Anderson et al., 2012). To address such a sample selection issue, we use a Heckman model for testing.

Table A.9 reports the coefficient estimates for these two model regressions (Models 1-3 for the Tobit and Models 4-6 for the Heckman regressions). In these models, we use interaction terms between vega and family involvement (the binary variables or continuous variables that capture executive ownership) to examine how family presence affects R\&D through incentive pay, apart from the effects of these incentives themselves. ${ }^{20}$ We

\footnotetext{
${ }^{20}$ For the purpose of our study, we should also include the standalone family variables in the regressions. But, due to very high correlations between these family variables and their interaction terms (with vega), we include the interaction terms only. Hence, their coefficient estimates represent total effects as in our model specification that proxy for family preference without being able to identify indirect (mediating) effects through incentive pay.
} 
also include all control variables (and the industry and year fixed effects) used in our main analysis of R\&D (as in Table A.4). Generally speaking, delta decreases and vega increases capital input for risky R\&D investments, consistent with our previous results. However, we do not find that R\&D efforts are discouraged in (active) family firms, which is inconsistent with the risk aversion hypothesis found in our previous analysis. Intriguingly, passive family firms invest more in $R \& D$, compared with nonfamily firms, which is effectively consistent with the investment horizon hypothesis. The estimates of the control variables are qualitatively similar to Table A.4. Overall, our main results still hold with these alternative model choices, although these models suggest a stronger family preference for horizons than for lower risk.

\section{[Please insert Table A.9 here]}

One of the primary and typical issues concerns endogeneity. That is, family presence or ownership is not random and is thus determined by investment policy itself or some unobservable factors (and can be common with factors that determine investment policy). This notion has been supported by a number of empirical studies. $^{21}$ To address such concerns and examine causal relations between family firms and their investment choices, following Anderson et al. (2012), we employ an instrumental variable two-stage Tobit model that allows for endogenous variables. We use CEO duality as the instrument for the two family variables. Similarly, we use interaction terms to examine the influence of families, again with a set of control variables as well as industry and time fixed effects. The results are reported in Table A.9 (Models 7-10). Again, vega itself increases $R \& D$, which is reduced (through incentive pay) in active family firms. The level of $R \& D$ is higher (through incentive pay) in passive family firms. These results further indicate that after controlling for endogeneity, the risk aversion hypothesis dominates in active family firms, while the investment horizon hypothesis dominates in passive family firms.

\section{Discussion and Implications}

Our paper studies two hypotheses of family preferences on investment decisions. We focus on one pay incentive vega that motivates the decision to allocate capital to risky investments in family firms. This is one main innovative element of our study. To further our understanding, here we re-examine the relations between family presence/ownership and vega. Because of the risk aversion preference, concentrated ownership is hypothesized as being associated with low vega. Nevertheless, we expect firm age to be critical in vega,

\footnotetext{
${ }^{21}$ See, for instance, Pindado, Requejo, and de la Torre (2012).
} 
conditional on ownership. For instance, an old firm typically faces scarce growth opportunities and might need a higher level of vega to induce managerial efforts for long-term and risky investments that ensure firm prosperity. Figure A.5 displays three contour plots of firm age, executive (family) ownership, and vega in three types of family firms. These plots provide evidence for our conjecture. For each firm type, there are areas of high vega (in colors red and yellow) located on the middle-right side of the plot. Hence, high vega (together with substantial ownership) is provided by some old firms, although less so in active family firms, which suggests the risk aversion hypothesis. Interestingly, for active family firms, there is one area of high vega (in red) located on the bottom-left side of the plot. This indicates that high vega is provided by some young active family firms, which supports the horizon hypothesis.

[Please insert Figure A.5 here]

We also find that the relation between firm age and ownership is positive (slightly concave) for active family firms, although there seems to be no linear relation for passive and nonfamily firms. ${ }^{22}$ This suggests that ownership accumulates over time for family CEOs only. Thus, for active family firms, in the early stage of business, delta is not very high because of (relatively) lower ownership, but vega can be very high due to risk seeking preferences (e.g., entrepreneurship). As firms age and begin to lack growth opportunities, vega can be high to motivate CEOs to engage in long-term investments. However, there are fewer such cases in active family firms because of family preference for lower risk.

\section{Conclusion}

Anderson et al. (2012) postulate that family preferences for risk and horizons potentially affect investment decisions that might not be in the best interest of nonfamily stakeholders. The authors offer evidence that families prefer to allocate financial resources to capital expenditures relative to risky R\&D investments and argue that this is because the risk aversion of these families outweighs the longer investment horizon of their long-term commitment. Another line of research on family firms indicates that these firms have different CEO pay structures compared with their nonfamily counterparts. Because pay incentives are likely to induce managerial behavior that enhances firm performance and investment decisions are value-critical observable decisions that CEOs make, it is plausible that families influence investment policy through pay incentives, in

\footnotetext{
${ }^{22}$ Relevant plots are not provided due to limited space and are available upon request.
} 
particular option vega. We hypothesize that CEO incentive pay mediates family preferences for lower risk and long horizons, which leads to different investment choices in firms with varying degrees of family involvement.

With a sample of 362 small U.S. publicly-traded companies from 2001 to 2005, we adopt a mediation model under a structural framework and find that active family firms have the lowest vega and the highest delta. Such incentive pay mediates approximately one-third of the underinvestment in risky $R \& D$ projects, especially for high-risk firms. Therefore, CEO incentive pay manifests the family preference for low risk in active family firms. Our results also demonstrate that passive family firms have higher R\&D compared to active family firms and conduct more M\&A deals, especially in low-risk firms. Hence, there is evidence for the family preference for horizons in passive family firms, but CEO incentive pay seems to mitigate, rather than manifest, such a preference. In our analysis, capital expenditures, usually viewed as less risky with a short-term feature, are not affected by family presence. This suggests that capital expenditure and R\&D may not necessarily be substitutes.

One main innovative aspect of our paper is that we connect seemingly unrelated strands of literature and identify one key channel that affects and/or manifests family preferences for investment choices. In general, our findings are in line with the earlier studies. For instance, consistent with Anderson et al. (2012), the finding that R\&D spending is the lowest in active family firms supports the family preference for lower firm risk. Moreover, we find a positive association between vega and $R \& D$. This piece of evidence suggests that higher vega induces risk-seeking managerial behavior, resulting in more riskier investments, which is consistent with the literature on option vega (e.g., Nam et al., 2003; Coles et al., 2006; DeYoung et al., 2013). Furthermore, similar to Li, Ryan, and Wang (2012), we show that vega is lower in family firms. Altogether, we add to the literature and demonstrate that CEO incentive pay affects investment decisions in family firms.

Overall, our paper provides evidence that CEO incentive pay is one important mechanism that influences corporate investment policy in family firms. Using CEO family affiliation and family ownership to identify family firms helps us test both the risk aversion and the investment horizon hypotheses in a more accurate manner. Our analysis suggests that the family preference to mitigate risk dominates in firms with a high degree of family involvement and that such a preference gives way to a horizon preference when family involvement is reduced. These patterns affect managerial compensation structure. One important implication for nonfamily shareholders in active family firms is that moderating incentive pay is one effective way to address issues of R\&D underinvestment. Nevertheless, higher R\&D in passive family firms with high idiosyncratic risk might not be a serious concern for nonfamily shareholders because this type of risk can be diversified away. Last but not least, our tests indicate that firms owned and run by families are considerably different from others, indicating 
that replacing a family member CEO with an outsider initiates the transition to a nonfamily firm. This also indicates that to avoid spurious relations, the classification of family firms should consider not only the ownership but also the control of the firm. 


\section{References}

Acock, A., 2013. Discovering structural equation modeling using Stata. Stata Press.

Aggarwal, R., Samwick, A., 1999. The other side of the tradeoff: the impact of risk on executive compensation. Journal of Political Economy, 107, 65-105.

Almeida, H., Campello, M., 2007. Financial constraints, asset tangibility, and corporate investment. Review of Financial Studies, 20(5), 1429-1460.

Anderson, R., Duru, A., Reeb, D., 2012. Investment policy in family controlled firms. Journal of Banking \& Finance, 36, 1744-1758.

Anderson, R., Reeb, D., 2003a. Founding-family ownership and firm performance: Evidence from the S\&P 500. Journal of Finance, 58(3), 1301-28.

Anderson, R., Reeb, D., 2003b. Founding family ownership, corporate diversification, and firm leverage. Journal of Law and Economics, 46, 653-684.

Barontini, R., Caprio, L., 2006. The effect of family control on firm value and performance: Evidence from continental Europe. European Financial Management, 12(5), 689-723.

Bartholomeusz, S., Tanewski, G., 2006. The Relationship between founding-family firms and corporate governance. Journal of Small Business Management, 44(2), 245-267.

Berger, P., Ofek, E., Yermack, D., 1997. Managerial entrenchment and capital structure decisions. Journal of Finance, 52, 1411-1438.

Bizjak, J., Brickley, J., Coles, J., 1993. Stock-based incentive compensation and investment behavior. Journal of Accounting and Economics, 16, 349-372.

Black, F., Scholes, M., 1973. The pricing of options and corporate liabilities. Journal of Political Economy, 81(3), 637-654.

Brainard, W.C., Tobin, J., 1968. Pitfalls in financial model building. American Economic Review, 58, 99-122.

Brockman, P., Martin, X., Unlu, E., 2010. Executive compensation and the maturity structure of corporate debt. Journal of Finance, 65, 1123-1161.

Celikyurt, U., Sevilir, M., Shivdasani., A., 2010. Going public to acquire? The acquisition motive in IPOs. Journal of Financial Economics, 96, 345-363.

Chen, S., Chen, X., Cheng, Q., Shevlin, T., 2010. Are family firms more tax aggressive than nonfamily firms? Journal of Financial Economics, 95, 41-61.

Chhaochharia, V., Grinstein, Y., 2009. CEO compensation and board structure. Journal of Finance, 64, 231-261.

Claessens, S., Djankov, S., Lang, L., 2000. The separation of ownership and control in East Asian corporations. Journal of Financial Economics, 58(1-2), 81-112.

Cohen, R., Hall, B., Viceira, L., 2000. Do executive stock options encourage risk-taking? Working Paper. Harvard Business School.

Coles, J., Daniel, N., Naveen, L., 2006. Managerial incentives and risk-taking, Journal of Financial Economics, 79, 431-468. 
Core, J., Guay, W., 1999. The use of equity grants to manage optimal equity incentive levels. Journal of Accounting and Economics, 28, 151-184.

Core, J., Guay, W., 2002. Estimating the value of employee stock option portfolios and their sensitivities to price and volatility. Journal of Accounting Research, 40, 613-630.

Datta, S., Iskandar-Datta, M., Raman, K., 2001. Executive compensation and corporate acquisition decisions. Journal of Finance, 56, 2299-2336.

Denis, D., Denis, D., Sarin, A., 1997. Agency problems, equity ownership, and corporate diversification. Journal of Finance, 52, 135-160.

DeYoung, R., Peng, E., Yan, M., 2013. Executive compensation and business policy choices at U.S. commercial banks. Journal of Financial and Quantitative Analysis, 48(1), 165-196.

Edmans, A., 2009. Blockholder trading, market efficiency, and managerial myopia. Journal of Finance 64, 2481-2513.

Faccio, M., Lang, L., 2002. The ultimate ownership of western European corporations. Journal of Financial Economics, 65(3), 365-95.

Fama, E., Jensen, M., 1985. Organizational forms and investment decisions. Journal of Financial Economics, 14, 101-119.

Gomez-Mejia, L., Larraza-Kintana, M., Makri, M., 2003. The determinants of executive compensation in family-controlled public corporations. Academy of Management Journal, 46(2), 226-237.

Gompers, P., Lerner, J., 2000. The determinants of corporate venture capital success: Organizational structure, incentives, and complementarities. In: Morck, R. (Ed.), Concentrated Corporate Ownership. University of Chicago Press for the National Bureau of Economic Research, Chicago.

Guay, W.R., 1999. The sensitivity of CEO wealth to equity risk: An analysis of the magnitude and determinants, Journal of Financial Economics, 43-71.

Hagendorff, J., Vallascas, F., 2011. CEO pay incentives and risk-taking: Evidence from bank acquisitions. Journal of Corporate Finance, 17, 1078-1095.

Hall, B.H., Jaffe, A., Trajtenberg, M., 2005. Market value and patent citations. Rand Journal of Economics, 36, 16-38.

Hall, B.J., Liebman, J.B., 1998. Are CEOs really paid like bureaucrats? Quarterly Journal of Economic 113, 653-691.

Haugen, R.A., Senbet, L.W., 1981. Resolving the agency problems of external capital through options. Journal of Finance, 36, 629-647.

Helwege, J., Pirinsky, C., Stulz, R.M., 2007. Why do firms become widely held? An analysis of the dynamics of corporate ownership. Journal of Finance, 62, 995-1028.

Holmstrom, B., 1979. Moral hazard and observability. Bell Journal of Economics, 10, 74-91.

Jensen, M.C., Meckling, H., 1976. Theory of the firm: Managerial behavior, agency costs, and ownership structure. Journal of Financial Economics, 3(4), 305-60.

Jensen, M.C., Murphy, K.J., 1990. Performance pay and top-management incentives. Journal of Political Economy, 98, 225-264. 
Ju, N., Leland, H., Senbet, L., 2002. Options, option repricing and severance packages in managerial compensation: Their effects on corporate risk. Working paper. University of Maryland.

Knopf, J., Nam Jr., J., Thornton, J., 2002. The volatility and price sensitivities of managerial stock option portfolios and corporate hedging. Journal of Finance 57, 801-814.

Kob, P., Reeb, D., 2014. R\&D disclosures. Working paper.

Kogan, L., Papanikolaou, D., Seru A., Stoffman, N., 2012. Technological innovation, resource allocation, and growth. Working paper.

Kothari, P., Laguerre, E., Leone, J., 2002. Capitalization versus expensing: Evidence on the uncertainty of future earnings from capital expenditures versus R\&D outlays. Review of Accounting Studies 7, 355-382.

La Porta, R., Lopez-de-Silanes, F., Shleifer, A., 1999. Corporate ownership around the world. Journal of Finance, 54(2), 471-517.

Lewellen, K., 2003. Financing decisions when managers are risk averse. Working paper. MIT.

Li, Z., Ryan, H., Wang, L., 2012. Top management compensation incentives in family firms. Working paper.

Low, A., 2009. Managerial risk-taking behavior and equity-based compensation. Journal of Financial Economics, 92, 470-490.

Mazur, M., Wu, B., 2014. Founding family Firms, CEO incentive pay, and dual agency problems. Journal of Small Business Management, forthcoming.

Mehran, H., 1995. Executive compensation structure, ownership, and firm performance. Journal of Financial Economics, 38, 163-184.

Merton, R., 1976. Option pricing when underlying stock returns are discontinuous. Journal of Financial Economics, 3(1-2), 125-144.

Miller, D., Le Breton-Miller, I., Lester, R.H., Cannella, A.A., 2007. Are family firms really superior performers? Journal of Corporate Finance, 13, 829-858.

Morck, R., Stangeland, D., Yeung, B., 2000. Inherited Wealth, Corporate control, and economic growth: The Canadian disease? In concentrated corporate ownership, ed. Randall K. Morck, 319-69. Chicago: University of Chicago Press.

Myers, S.C., Majluf, N.S., 1984. Corporate financing and investment decisions when firms have information that investors do not have. Journal of Financial Economics, 13, 187-221.

Nam, J., Ottoo, R., Thornton Jr., J., 2003. The effect of managerial incentives to bear risk on corporate investment and R\&D investment. Financial Review, 38, 77-101.

Parrino, R., Poteshman, A., Weisbach, M., 2005. Measuring investment distortions when risk-averse managers decide whether to undertake risky projects. Financial Management, 34, 21-60.

Pindado, J., Requejo, I., de la Torre, C., 2012. Do family firms use dividend policy as a governance mechanism? Evidence from the euro zone. Corporate Governance: An International Review 20(5), 413-431.

Rajgopal, S., Shevlin, T., 2002. Empirical evidence on the relation between stock option compensation and risk-taking. Journal of Accounting and Economics 33, 145-171. 
Rogers, D., 2002. Does executive portfolio structure affect risk management? CEO risk-taking incentives and corporate derivatives usage. Journal of Banking and Finance, 26, 271-295.

Ross, S., 2004. Compensation, incentives, and the duality of risk aversion and riskiness. Journal of Finance, 59, 207-225.

Schulze, W., Lubatkin, M., Dino, R., Buchholtz, A., 2001. Agency relationships in founding-family firms: Theory and evidence. Organization Science, 12(2), 99-116.

Shleifer, A., Vishny, R., 1986. Large shareholders and corporate control. Journal of Political Economy, 94(3), 461-88.

Smith, C.W., Stulz, R.M., 1985. The determinants of firms' hedging policies. Journal of Financial and Quantitative Analysis, 20, 391-405.

Stein, J., 1988. Threats and managerial myopia. Journal of Political Economy, 96, 61-80.

Tobin, J., 1969. A General Equilibrium Approach to Monetary Theory. Journal of Money, Credit, and Banking, 1, 15-29.

Tomarken, A., Waller, N., 2005. Structural equation modeling: strengths, limitations, and misconceptions. Annual Review of Clinical Psychology, 1(1), 31-65.

Villalonga, B., Amit, R., 2006. How do family ownership, control, and management affect firm value? Journal of Financial Economics, 80, 385-417.

Whited, T.M., 2006. External finance constraints and the intertemporal pattern of intermittent investment. Journal of Financial Economics, 81, 467-502. 


\section{Table A.1}

Variable definitions and descriptive statistics on CEO and firm characteristics

\begin{tabular}{|c|c|c|c|c|c|c|c|}
\hline Variable & Definition & Data Source & Mean & Median & Std. dev. & Max. & Min. \\
\hline \multicolumn{8}{|l|}{ CEO-specific: } \\
\hline$\overline{\text { Delta* }(\$ M)}$ & $\begin{array}{l}\text { The change in the value of the CEO's } \\
\text { stock holding and option portfolio in } \\
\text { response to a } 1 \% \text { change in the firm's } \\
\text { stock price }\end{array}$ & $\begin{array}{l}\text { Calculation following Core and Guay (2002) and Brockman } \\
\text { et al. (2010) with data from ExecuComp }\end{array}$ & 299.19 & 132.14 & 582.82 & $8,277.63$ & 0.00 \\
\hline Vega* $(\$ M)$ & $\begin{array}{l}\text { The change in the value of the CEO's } \\
\text { option portfolio in response to a } 1 \% \\
\text { change in stock return volatility }\end{array}$ & $\begin{array}{l}\text { Calculation following Core and Guay (2002) and Brockman } \\
\text { et al. (2010) with data from ExecuComp }\end{array}$ & 49.63 & 30.80 & 63.78 & 730.75 & 0.00 \\
\hline $\begin{array}{l}\text { Cash compensation* } \\
(\$ M)\end{array}$ & The sum of the CEO's salary and bonus & ExecuComp item total_curr & 870.04 & 680.55 & 920.19 & $21,119.34$ & 0.00 \\
\hline Ownership* (\%) & $\begin{array}{l}\text { Percentage of CEO shareholding, } \\
\text { including the holdings of family } \\
\text { members, if applicable }\end{array}$ & Proxy statements & 8.23 & 2.50 & 14.47 & 81.20 & 0.00 \\
\hline Share ownership (\%) & $\begin{array}{l}\text { Percentage of executive shareholding } \\
\text { (excluding options) }\end{array}$ & $\begin{array}{l}\text { ExecuComp item shrown_excl_opts scaled by Compustat } \\
\text { item shrsout }\end{array}$ & 3.50 & 0.68 & 7.59 & 62.76 & 0.00 \\
\hline Executive age* & Age of the CEO & ExecuComp item age & 55.48 & 55.00 & 7.71 & 84.00 & 29.00 \\
\hline \multicolumn{8}{|l|}{ Firm-specific: } \\
\hline Firm size* (\$MM) & Annual total sales & Compustat item sale & 805.40 & 503.41 & $1,004.71$ & $10,973.32$ & 0.00 \\
\hline Firm age* & $\begin{array}{l}\text { Difference between the founding year } \\
\text { and the data year }\end{array}$ & Online sources (e.g., www.funduniverse.com) & 47.35 & 36.00 & 35.01 & 230.00 & 0.00 \\
\hline Cash ratio & Cash scaled by total assets & Compustat item $c h / a t$ & 0.12 & 0.07 & 0.12 & 0.78 & 0.00 \\
\hline Leverage ratio & $\begin{array}{l}\text { Year-end long-term debt scaled by total } \\
\text { assets }\end{array}$ & Compustat items dltt/at & 0.16 & 0.12 & 0.16 & 1.62 & 0.00 \\
\hline Asset tangibility ratio & $\begin{array}{l}\text { Total property, plant and equipment } \\
\text { scaled by total assets }\end{array}$ & Compustat item ppent/at & 0.25 & 0.19 & 0.20 & 0.96 & 0.00 \\
\hline Dividend ratio & $\begin{array}{l}\text { Firm's annual cash dividends scaled by } \\
\text { total assets }\end{array}$ & Compustat item $d v / a t$ & 0.01 & 0.00 & 0.02 & 0.45 & 0.00 \\
\hline Firm risk & $\begin{array}{l}\text { Standard deviation volatility over the } \\
\text { past } 60 \text { months }\end{array}$ & Compustat item bs_volatility & 0.55 & 0.51 & 0.21 & 1.53 & 0.18 \\
\hline Market risk (\%) & $\begin{array}{l}\text { Beta coefficient estimated from the three- } \\
\text { factor market model over a year }\end{array}$ & $\begin{array}{l}\text { CRSP item retx and factors data on Kenneth R. French's } \\
\text { website }\end{array}$ & 1.13 & 1.09 & 0.52 & 5.90 & -6.81 \\
\hline $\begin{array}{l}\text { Idiosyncratic risk } \\
(\%)\end{array}$ & $\begin{array}{l}\text { Standard deviation of the three-factor } \\
\text { market model residuals over a year }\end{array}$ & $\begin{array}{l}\text { CRSP item retx and factors data on Kenneth R. French’s } \\
\text { website }\end{array}$ & 2.92 & 2.61 & 1.35 & 14.77 & 0.96 \\
\hline
\end{tabular}




\begin{tabular}{|c|c|c|c|c|c|c|c|}
\hline Return on assets & $\begin{array}{l}\text { A ratio of earnings before interest and tax } \\
\text { scaled by total assets }\end{array}$ & Compustat items ebit/at & 0.08 & 0.08 & 0.12 & 0.66 & -1.65 \\
\hline Tobin’s Q ${ }^{+}$ & $\begin{array}{l}\text { Market-to-book ratio, defined as total } \\
\text { assets plus the market value of common } \\
\text { stock less the sum of book value of } \\
\text { common equity and balance sheet } \\
\text { deferred taxes scaled by total assets }\end{array}$ & Compustat items (at+csho*(prcc_f-bkvlps)-txdb)/at & 1.79 & 1.46 & 1.07 & 11.13 & 0.40 \\
\hline CAPEX & $\begin{array}{l}\text { Capital expenditures scaled by total } \\
\text { assets }\end{array}$ & Compsutat items capx/at & 0.05 & 0.03 & 0.06 & 0.82 & 0.00 \\
\hline R\&D & R\&D expenditures scaled by total assets & Compsutat items $x r d / a t$ & 0.03 & 0.00 & 0.06 & 0.40 & 0.00 \\
\hline M\&A number* & Firm’s number of M\&A deals & Security Data Corporation & 0.59 & 0.00 & 1.05 & 9.00 & 0.00 \\
\hline M\&A value & $\begin{array}{l}\text { Sum of the M\&A deal value scaled by } \\
\text { the firm's market value of equity }\end{array}$ & Security Data Corporation & 0.03 & 0.00 & 0.12 & 2.43 & 0.00 \\
\hline GIM index & $\begin{array}{l}\text { Follows Gompers, Ishii, and Metrick } \\
\text { (2003) }\end{array}$ & RiskMetrics Governance Legacy item gindex & 8.76 & 9.00 & 2.63 & 17.00 & 2.00 \\
\hline Entrenchment index & $\begin{array}{l}\text { Follows Bebchuk, Cohen, and Ferrell } \\
\text { (2004) }\end{array}$ & $\begin{array}{l}\text { RiskMetrics Governance Legacy items } \\
\text { cboard+supermajor+ppill+goldenparachute+lachtr+labylw }\end{array}$ & 2.20 & 2.00 & 1.29 & 5.00 & 0.00 \\
\hline Board size & Number of directors on the board & RiskMetrics Directors Directors Legacy & 7.89 & 8.00 & 1.94 & 15.00 & 1.00 \\
\hline CEO duality (0/1) & $\begin{array}{l}\text { Binary variable that equals one when the } \\
\text { CEO serves as company chairman }\end{array}$ & ExecuComp item titleann & 0.52 & 1.00 & 0.50 & 1.00 & 0.00 \\
\hline Patent number* & The number of patents filed over a year & Bronwyn Hall's patent database & 2.38 & 0.00 & 6.31 & 83.00 & 0.00 \\
\hline Patent citation* & $\begin{array}{l}\text { The number of citations of filed patents } \\
\text { over a year }\end{array}$ & Bronwyn Hall's patent database & 16.29 & 0.00 & 68.40 & $1,511.00$ & 0.00 \\
\hline
\end{tabular}

From Table A.3 onwards, the variables with symbols * and ${ }^{+}$are scaled by natural logarithm and are winsorized at the top $1 \%$ level, respectively. 
Table A.2

Comparisons of selected characteristics among firm types

\begin{tabular}{|c|c|c|c|c|c|c|c|c|c|}
\hline \multirow[t]{2}{*}{ Variable } & \multicolumn{2}{|c|}{$\begin{array}{l}\text { Active Family } \\
\text { Firms }\end{array}$} & \multicolumn{2}{|c|}{$\begin{array}{l}\text { Passive Family } \\
\text { Firms }\end{array}$} & \multicolumn{2}{|c|}{$\begin{array}{l}\text { Non Family } \\
\text { Firms }\end{array}$} & \multicolumn{3}{|c|}{$\begin{array}{l}\mathrm{p} \text {-Value of Test for Diff. in } \\
\text { Means (Distribution) }\end{array}$} \\
\hline & Mean & Median & Mean & Median & Mean & Median & II-I & III－II & III-I \\
\hline \multicolumn{10}{|l|}{ CEO-specific: } \\
\hline Delta (\$M) & 611.08 & 310.82 & 144.01 & 98.70 & 165.46 & 92.16 & $\begin{array}{r}0 \\
(0)\end{array}$ & $\begin{array}{r}0.0992 \\
(0.1994)\end{array}$ & $\begin{array}{r}0 \\
(0)\end{array}$ \\
\hline Vega (\$M) & 47.41 & 25.06 & 42.06 & 30.30 & 54.79 & 36.32 & $\begin{array}{r}0.2047 \\
(0.0201)\end{array}$ & $\begin{array}{r}0.0003 \\
(0.0007)\end{array}$ & $\begin{array}{r}0.0531 \\
(0)\end{array}$ \\
\hline $\begin{array}{l}\text { Cash compensation } \\
(\$ \mathrm{M})\end{array}$ & 897.96 & 611.33 & 842.08 & 693.90 & 864.88 & 700.00 & $\begin{array}{r}0.4416 \\
(0.0031)\end{array}$ & $\begin{array}{r}0.5745 \\
(0.2488)\end{array}$ & $\begin{array}{r}0.542 \\
(0)\end{array}$ \\
\hline Ownership (\%) & 20.09 & 12.27 & 2.57 & 1.50 & 3.04 & 1.80 & $\begin{array}{r}0 \\
(0)\end{array}$ & $\begin{array}{r}0.201 \\
(0.0001)\end{array}$ & $\begin{array}{r}0 \\
(0)\end{array}$ \\
\hline Share ownership (\%) & 9.01 & 4.61 & 1.13 & 0.33 & 0.96 & 0.39 & $\begin{array}{r}0 \\
(0)\end{array}$ & $\begin{array}{l}0.2854 \\
(0.113)\end{array}$ & $\begin{array}{r}0 \\
(0)\end{array}$ \\
\hline Executive age & 56.88 & 58.00 & 54.45 & 54.00 & 55.04 & 55.00 & $\begin{array}{r}0 \\
(0)\end{array}$ & $\begin{array}{r}0.1671 \\
(0.0945)\end{array}$ & $\begin{array}{r}0 \\
(0)\end{array}$ \\
\hline$\frac{\text { FIrm-spe }}{\text { Firm siz }}$ & 838.50 & 417.68 & 806.23 & 533.21 & 782.83 & 546.80 & $\begin{array}{r}0.6749 \\
(0.0027)\end{array}$ & $\begin{array}{r}0.6359 \\
(0.963)\end{array}$ & $\begin{array}{r}0.3355 \\
(0.0003)\end{array}$ \\
\hline Firm age & 38.03 & 30.00 & 47.79 & 38.00 & 53.39 & 44.00 & $\begin{array}{r}0 \\
(0.0001)\end{array}$ & $\begin{array}{r}0.0143 \\
(0.0157)\end{array}$ & $\begin{array}{r}0 \\
(0)\end{array}$ \\
\hline Cash ratio & 0.13 & 0.09 & 0.11 & 0.07 & 0.11 & 0.06 & $\begin{array}{l}0.0901 \\
(0.303)\end{array}$ & $\begin{array}{r}0.4714 \\
(0.082)\end{array}$ & $\begin{array}{r}0.0057 \\
(0.0036)\end{array}$ \\
\hline Leverage ratio & 0.14 & 0.06 & 0.14 & 0.09 & 0.17 & 0.16 & $\begin{array}{r}0.9454 \\
(0.5201)\end{array}$ & $\begin{array}{r}0.0031 \\
(0.0005)\end{array}$ & $\begin{array}{r}0.0019 \\
(0)\end{array}$ \\
\hline Asset tangibility ratio & 0.23 & 0.17 & 0.24 & 0.18 & 0.27 & 0.21 & $\begin{array}{r}0.2962 \\
(0.3042)\end{array}$ & $\begin{array}{r}0.0491 \\
(0.0106)\end{array}$ & $\begin{array}{r}0.0005 \\
(0.0001)\end{array}$ \\
\hline Dividend ratio & 0.01 & 0.00 & 0.01 & 0.00 & 0.01 & 0.00 & $\begin{array}{r}0.0017 \\
(0)\end{array}$ & $\begin{array}{r}0.0083 \\
(0)\end{array}$ & $\begin{array}{r}0.6484 \\
(0.1565)\end{array}$ \\
\hline Firm risk & 0.59 & 0.57 & 0.53 & 0.48 & 0.53 & 0.48 & $\begin{array}{r}0 \\
(0)\end{array}$ & $\begin{array}{r}0.9099 \\
(0.8458)\end{array}$ & $\begin{array}{r}0 \\
(0)\end{array}$ \\
\hline Market risk (\%) & 1.16 & 1.13 & 1.13 & 1.08 & 1.10 & 1.06 & $\begin{array}{r}0.4947 \\
(0.4525)\end{array}$ & $\begin{array}{r}0.349 \\
(0.1732)\end{array}$ & $\begin{array}{r}0.0967 \\
(0.0314)\end{array}$ \\
\hline Idiosyncratic risk (\%) & 3.16 & 2.82 & 2.89 & 2.49 & 2.77 & 2.48 & $\begin{array}{r}0.0076 \\
(0.0003)\end{array}$ & $\begin{array}{r}0.1798 \\
(0.5641)\end{array}$ & $\begin{array}{r}0 \\
(0)\end{array}$ \\
\hline Return on assets & 0.08 & 0.09 & 0.08 & 0.08 & 0.08 & 0.08 & $\begin{array}{r}0.6283 \\
(0.9407)\end{array}$ & $\begin{array}{r}0.7569 \\
(0.4473)\end{array}$ & $\begin{array}{r}0.7838 \\
(0.4808)\end{array}$ \\
\hline Tobin’s Q & 1.83 & 1.54 & 1.89 & 1.49 & 1.70 & 1.41 & $\begin{array}{r}0.3717 \\
(0.8065)\end{array}$ & $\begin{array}{r}0.0038 \\
(0.0033)\end{array}$ & $\begin{array}{r}0.0275 \\
(0.0046)\end{array}$ \\
\hline CAPEX & 0.05 & 0.03 & 0.05 & 0.03 & 0.05 & 0.03 & $\begin{array}{r}0.6234 \\
(0.842)\end{array}$ & $\begin{array}{r}0.9704 \\
(0.3457)\end{array}$ & $\begin{array}{r}0.4953 \\
(0.4025)\end{array}$ \\
\hline $\mathrm{R} \& \mathrm{D}$ & 0.03 & 0.00 & 0.04 & 0.01 & 0.03 & 0.00 & $\begin{array}{r}0.0354 \\
(0.0617)\end{array}$ & $\begin{array}{r}0.0573 \\
(0.0269)\end{array}$ & $\begin{array}{r}0.7945 \\
(0.7375)\end{array}$ \\
\hline M\&A number & 0.58 & 0.00 & 0.70 & 0.00 & 0.54 & 0.00 & $\begin{array}{r}0.1148 \\
(0.0195)\end{array}$ & $\begin{array}{r}0.0154 \\
(0.0255)\end{array}$ & $\begin{array}{r}0.535 \\
(0.6795)\end{array}$ \\
\hline M\&A value & 0.02 & 0.00 & 0.04 & 0.00 & 0.04 & 0.00 & $\begin{array}{r}0.0621 \\
(0.0393)\end{array}$ & $\begin{array}{r}0.6033 \\
(0.2522)\end{array}$ & $\begin{array}{r}0.0204 \\
(0.2716)\end{array}$ \\
\hline GIM index & 7.99 & 8.00 & 8.94 & 9.00 & 9.17 & 9.00 & $\begin{array}{r}0 \\
(0)\end{array}$ & $\begin{array}{r}0.2412 \\
(0.3927)\end{array}$ & $\begin{array}{r}0 \\
(0)\end{array}$ \\
\hline Entrenchment index & 1.73 & 2.00 & 2.17 & 2.00 & 2.53 & 3.00 & $\begin{array}{r}0 \\
(0)\end{array}$ & $\begin{array}{r}0.0001 \\
(0.0003)\end{array}$ & $\begin{array}{r}0 \\
(0)\end{array}$ \\
\hline Board size & 7.56 & 7.00 & 8.38 & 8.00 & 7.87 & 8.00 & $\begin{array}{r}0 \\
(0)\end{array}$ & $\begin{array}{r}0.0001 \\
(0.0008)\end{array}$ & $\begin{array}{r}0.0104 \\
(0.0006)\end{array}$ \\
\hline CEO duality (0/1) & 0.68 & 1.00 & 0.34 & 0.00 & 0.50 & 1.00 & $\begin{array}{r}0 \\
(0)\end{array}$ & $\begin{array}{r}0 \\
(0)\end{array}$ & $\begin{array}{r}0 \\
(0)\end{array}$ \\
\hline Patent number & 1.91 & 0.00 & 2.86 & 0.00 & 2.47 & 0.00 & 0.013 & 0.3572 & 0.0965 \\
\hline
\end{tabular}




\begin{tabular}{|c|c|c|c|c|c|c|c|c|c|}
\hline & & & & & & & $(0.1231)$ & (0.3891) & (0.3733) \\
\hline Patent citation & 15.18 & 0.00 & 19.64 & 0.00 & 15.42 & 0.00 & $\begin{array}{r}0.3837 \\
(0.0896)\end{array}$ & $\begin{array}{r}0.3186 \\
(0.4728)\end{array}$ & $\begin{array}{r}0.9436 \\
(0.2213)\end{array}$ \\
\hline \# of obs. & & 546 & & 395 & & 815 & & & \\
\hline
\end{tabular}

See Table A.1 for variable definitions.

This table presents means and medians of variables in Table A.1 with respect to three subgroups of our sample firms. Type I firm is active founding-family firm, i.e., controlled and run by founding family; Type II firm is passive founding-family firm, i.e., controlled but not run by founding family; Type III firm is non-foundingfamily firm, i.e., neither controlled nor run by founding family.

Figure A.1

Simple illustration of baseline structural equation model

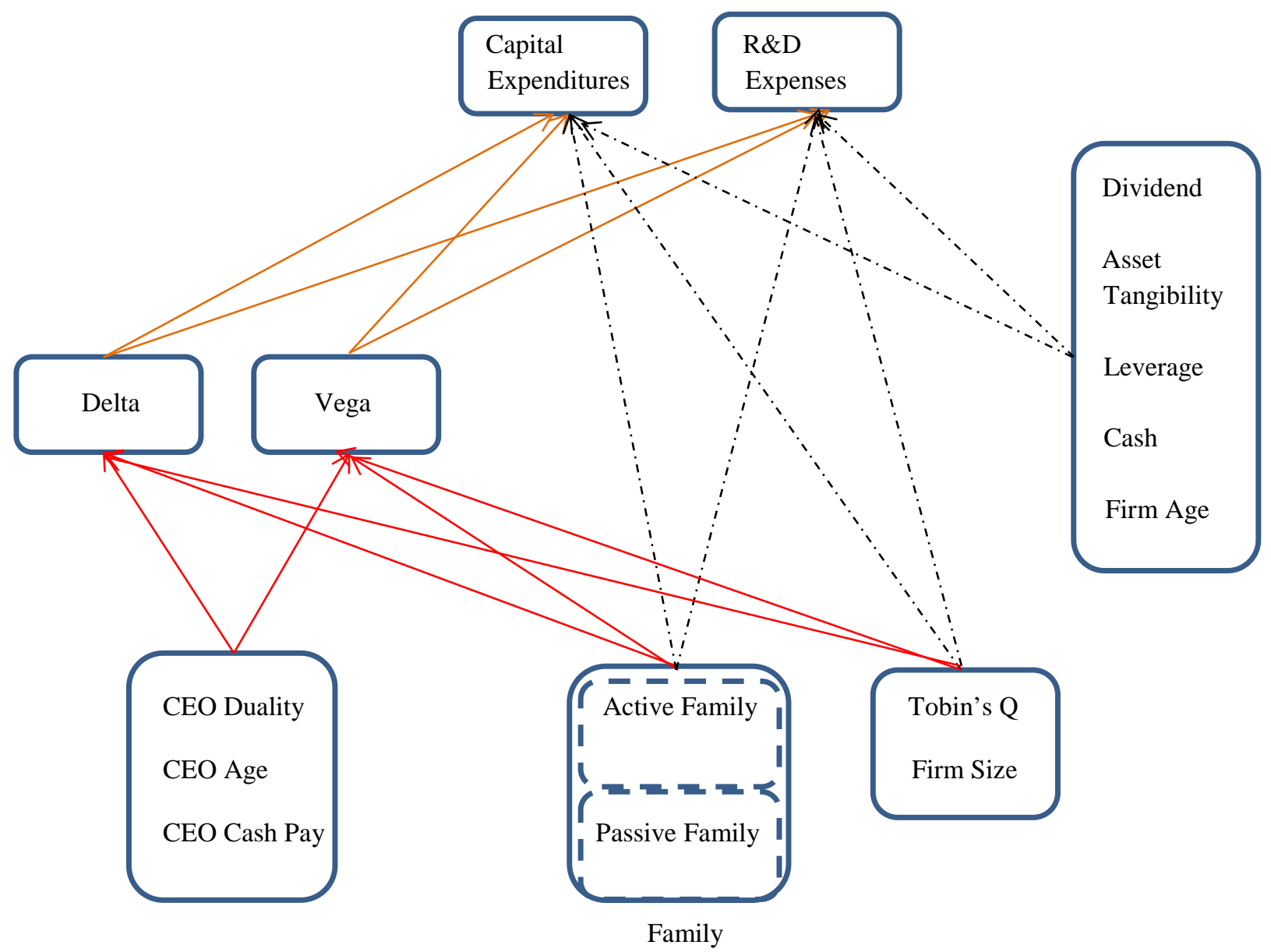

A path is typically shown as an arrow, drawn from one variable to another, and establishes the relation (causality) between these two variables. 
Table A.3

Correlation matrix of key variables

\begin{tabular}{|c|c|c|c|c|c|c|c|c|c|c|c|c|c|c|c|c|c|}
\hline & & 1 & 2 & 3 & 4 & 5 & 6 & 7 & 8 & 9 & 10 & 11 & 12 & 13 & 14 & 15 & 16 \\
\hline 1 & CAPEX & 1 & & & & & & & & & & & & & & & \\
\hline 2 & $\mathrm{R} \& \mathrm{D}$ & $-0.09 *$ & 1 & & & & & & & & & & & & & & \\
\hline 3 & M\&A number & $-0.11 *$ & 0.01 & 1 & & & & & & & & & & & & & \\
\hline 4 & M\&A value & $-0.09 *$ & 0.05 & $0.69 *$ & 1 & & & & & & & & & & & & \\
\hline 5 & Delta & $0.07 *$ & -0.06 & 0.04 & 0.02 & 1 & & & & & & & & & & & \\
\hline 6 & Vega & -0.05 & 0.00 & $0.11^{*}$ & $0.09 *$ & $0.35 *$ & 1 & & & & & & & & & & \\
\hline 7 & Firm size & -0.03 & $-0.53^{*}$ & $0.07 *$ & 0.04 & $0.12 *$ & $0.17^{*}$ & 1 & & & & & & & & & \\
\hline 8 & Tobin's Q & $0.12 *$ & $0.31^{*}$ & -0.02 & -0.04 & $0.27 *$ & $0.06^{*}$ & $-0.34 *$ & 1 & & & & & & & & \\
\hline 9 & Firm age & $-0.10 *$ & $-0.26 *$ & -0.05 & -0.04 & $-0.12 *$ & 0.03 & $0.37 *$ & $-0.27 *$ & 1 & & & & & & & \\
\hline 10 & Cash ratio & $-0.07 *$ & $0.39 *$ & $-0.09 *$ & $-0.07 *$ & $0.07 *$ & -0.04 & $-0.43^{*}$ & $0.37 *$ & $-0.25^{*}$ & 1 & & & & & & \\
\hline 11 & Leverage ratio & 0.03 & $-0.22 *$ & $0.07 *$ & $0.11^{*}$ & $-0.11^{*}$ & $0.07 *$ & $0.32 *$ & $-0.27 *$ & $0.19 *$ & $-0.35 *$ & 1 & & & & & \\
\hline 12 & Asset tangibility & $0.57^{*}$ & $-0.29 *$ & $-0.14^{*}$ & $-0.09 *$ & -0.02 & $-0.07 *$ & $0.13^{*}$ & $-0.13^{*}$ & $0.10^{*}$ & $-0.29 *$ & $0.28 *$ & 1 & & & & \\
\hline 13 & Dividend ratio & -0.06 & $-0.08 *$ & $-0.07 *$ & -0.06 & $-0.08 *$ & -0.05 & 0.04 & 0.01 & $0.16^{*}$ & $-0.07 *$ & -0.06 & -0.02 & 1 & & & \\
\hline 14 & CEO duality & 0.03 & $-0.14^{*}$ & 0.00 & -0.02 & $0.21 *$ & $0.09 *$ & $0.12 *$ & -0.05 & $0.10^{*}$ & -0.04 & 0.06 & 0.03 & -0.03 & 1 & & \\
\hline 15 & CEO age & -0.06 & $-0.10 *$ & -0.05 & -0.04 & $0.11^{*}$ & $-0.10 *$ & $0.10^{*}$ & $-0.14^{*}$ & $0.22 *$ & $-0.14 *$ & 0.06 & 0.04 & 0.04 & $0.20^{*}$ & 1 & \\
\hline 16 & Cash pay & $-0.07 *$ & $-0.18^{*}$ & $0.07 *$ & $0.08^{*}$ & $0.14^{*}$ & $0.27 *$ & $0.42 *$ & -0.05 & $0.17^{*}$ & $-0.08^{*}$ & $0.15^{*}$ & 0.02 & 0.03 & $0.12 *$ & 0.04 & 1 \\
\hline
\end{tabular}

See Table A.1 for variable definitions. The symbols * represents statistical significance at the 0.01 level. 
Table A.4

Family firms, CEO option sensitivities, and corporate investments

\begin{tabular}{|c|c|c|c|c|c|c|c|c|c|c|c|c|}
\hline & \multicolumn{6}{|c|}{ Model 1} & \multicolumn{6}{|c|}{ Model 2} \\
\hline & \multicolumn{2}{|c|}{ Direct Effect } & \multicolumn{2}{|c|}{ Indirect Effect } & \multicolumn{2}{|c|}{ Total Effect } & \multicolumn{2}{|c|}{ Direct Effect } & \multicolumn{2}{|c|}{ Indirect Effect } & \multicolumn{2}{|c|}{ Total Effect } \\
\hline & CAPEX & $\mathrm{R} \& \mathrm{D}$ & CAPEX & $\mathrm{R} \& \mathrm{D}$ & CAPEX & $\mathrm{R} \& \mathrm{D}$ & CAPEX & $\mathrm{R} \& \mathrm{D}$ & CAPEX & $\mathrm{R} \& \mathrm{D}$ & CAPEX & $\mathrm{R} \& \mathrm{D}$ \\
\hline Family & $\begin{array}{l}0.0044 \\
(1.38)\end{array}$ & $\begin{array}{l}-0.0004 \\
(-0.09)\end{array}$ & $\begin{array}{l}0.0000 \\
(0.001)\end{array}$ & $\begin{array}{l}-0.0033^{* *} \\
(-2.34)\end{array}$ & $\begin{array}{l}0.0044 \\
(1.29)\end{array}$ & $\begin{array}{l}-0.0037 \\
(-0.85)\end{array}$ & & & & & & \\
\hline Active family & & & & & & & $\begin{array}{l}0.0060 \\
(1.24)\end{array}$ & $\begin{array}{l}-0.0068 \\
(-1.2)\end{array}$ & $\begin{array}{l}-0.0004 \\
(-0.2)\end{array}$ & $\begin{array}{l}-0.0032 \\
(-1.31)\end{array}$ & $\begin{array}{l}0.0056 \\
(1.16)\end{array}$ & $\begin{array}{l}-0.0100 * \\
(-1.96)\end{array}$ \\
\hline Passive family & & & & & & & $\begin{array}{l}0.0030 \\
(0.92)\end{array}$ & $\begin{array}{l}0.0050 \\
(0.88)\end{array}$ & $\begin{array}{l}-0.0003 \\
(-0.77)\end{array}$ & $\begin{array}{l}-0.0004 \\
(-0.86)\end{array}$ & $\begin{array}{l}0.0028 \\
(0.86)\end{array}$ & $\begin{array}{l}0.0046 \\
(0.82)\end{array}$ \\
\hline Delta & $\begin{array}{l}0.001 \\
(0.36)\end{array}$ & $\begin{array}{l}-0.004^{* *} \\
(-2)\end{array}$ & & & $\begin{array}{l}0.001 \\
(0.36)\end{array}$ & $\begin{array}{l}-0.004 * * \\
(-2)\end{array}$ & $\begin{array}{l}0.000 \\
(0.06)\end{array}$ & $\begin{array}{l}-0.002 \\
(-1.01)\end{array}$ & & & $\begin{array}{l}0.000 \\
(0.06)\end{array}$ & $\begin{array}{l}-0.002 \\
(-1.01)\end{array}$ \\
\hline Vega & $\begin{array}{l}0.001 \\
(0.61)\end{array}$ & $\begin{array}{l}0.003^{* *} \\
(2.2)\end{array}$ & & & $\begin{array}{l}0.001 \\
(0.61)\end{array}$ & $\begin{array}{l}0.003^{* *} \\
(2.2)\end{array}$ & $\begin{array}{l}0.001 \\
(0.84)\end{array}$ & $\begin{array}{l}0.002 \\
(1.6)\end{array}$ & & & $\begin{array}{l}0.001 \\
(0.84)\end{array}$ & $\begin{array}{l}0.002 \\
(1.6)\end{array}$ \\
\hline Firm size & $\begin{array}{l}-0.001 \\
(-0.79)\end{array}$ & $\begin{array}{l}-0.019 * * * \\
(-6.11)\end{array}$ & $\begin{array}{l}0.000 \\
(0.67)\end{array}$ & $\begin{array}{l}-0.000 \\
(-0.95)\end{array}$ & $\begin{array}{l}-0.001 \\
(-0.68)\end{array}$ & $\begin{array}{l}-0.020 \text { *** } \\
(-6.35)\end{array}$ & $\begin{array}{l}-0.001 \\
(-0.7)\end{array}$ & $\begin{array}{l}-0.020^{* * *} \\
(-6.4)\end{array}$ & $\begin{array}{l}0.000 \\
(0.35)\end{array}$ & $\begin{array}{l}-0.000 \\
(-0.4)\end{array}$ & $\begin{array}{l}-0.001 \\
(-0.65)\end{array}$ & $\begin{array}{l}-0.020 * * * \\
(-6.55)\end{array}$ \\
\hline Tobin’s Q & $\begin{array}{l}0.007^{* * *} \\
(3.93)\end{array}$ & $\begin{array}{l}0.007 * * \\
(2.21)\end{array}$ & $\begin{array}{l}0.000 \\
(0.55)\end{array}$ & $\begin{array}{l}-0.001 \\
(-1.55)\end{array}$ & $\begin{array}{l}0.008^{* * *} \\
(4.59)\end{array}$ & $\begin{array}{l}0.006^{*} \\
(1.95)\end{array}$ & $\begin{array}{l}0.008^{* * *} \\
(4.17)\end{array}$ & $\begin{array}{l}0.006^{*} \\
(1.96)\end{array}$ & $\begin{array}{l}0.000 \\
(0.26)\end{array}$ & $\begin{array}{l}-0.000 \\
(-0.64)\end{array}$ & $\begin{array}{l}0.008^{* * *} \\
(4.63)\end{array}$ & $\begin{array}{l}0.006^{*} \\
(1.91)\end{array}$ \\
\hline Firm age & $\begin{array}{l}-0.005^{*} \\
(-1.81)\end{array}$ & $\begin{array}{l}-0.006 \\
(-1.62)\end{array}$ & & & $\begin{array}{l}-0.005^{*} \\
(-1.81)\end{array}$ & $\begin{array}{l}-0.006 \\
(-1.62)\end{array}$ & $\begin{array}{l}-0.004^{*} \\
(-1.75)\end{array}$ & $\begin{array}{l}-0.006^{*} \\
(-1.69)\end{array}$ & & & $\begin{array}{l}-0.004^{*} \\
(-1.75)\end{array}$ & $\begin{array}{l}-0.006^{*} \\
(-1.69)\end{array}$ \\
\hline Cash ratio & $\begin{array}{l}0.000 \\
(0.03)\end{array}$ & $\begin{array}{l}0.054 * * \\
(2.38)\end{array}$ & & & $\begin{array}{l}0.000 \\
(0.03)\end{array}$ & $\begin{array}{l}0.054^{* *} \\
(2.38)\end{array}$ & $\begin{array}{l}0.000 \\
(0.03)\end{array}$ & $\begin{array}{l}0.054^{* *} \\
(2.42)\end{array}$ & & & $\begin{array}{l}0.000 \\
(0.03)\end{array}$ & $\begin{array}{l}0.054^{* *} \\
(2.42)\end{array}$ \\
\hline Leverage ratio & $\begin{array}{l}-0.026 * * * \\
(-3.01)\end{array}$ & $\begin{array}{l}0.001 \\
(0.09)\end{array}$ & & & $\begin{array}{l}-0.026 * * * \\
(-3.01)\end{array}$ & $\begin{array}{l}0.001 \\
(0.09)\end{array}$ & $\begin{array}{l}-0.026 * * * \\
(-2.96)\end{array}$ & $\begin{array}{l}0.004 \\
(0.23)\end{array}$ & & & $\begin{array}{l}-0.026^{* * *} \\
(-2.96)\end{array}$ & $\begin{array}{l}0.004 \\
(0.23)\end{array}$ \\
\hline Asset tangibility & $\begin{array}{l}0.158^{* * *} \\
(5.97)\end{array}$ & $\begin{array}{l}-0.040^{* * *} \\
(-4.05)\end{array}$ & & & $\begin{array}{l}0.158^{* * *} \\
(5.97)\end{array}$ & $\begin{array}{l}-0.040^{* * *} \\
(-4.05)\end{array}$ & $\begin{array}{l}0.158^{* * *} \\
(5.92)\end{array}$ & $\begin{array}{l}-0.041^{* * *} \\
(-4.16)\end{array}$ & & & $\begin{array}{l}0.158^{* * *} \\
(5.92)\end{array}$ & $\begin{array}{l}-0.041^{* * *} \\
(-4.16)\end{array}$ \\
\hline Dividend ratio & $\begin{array}{l}-0.069 * \\
(-1.69)\end{array}$ & $\begin{array}{l}-0.203^{* *} \\
(-1.98)\end{array}$ & & & $\begin{array}{l}-0.069 * \\
(-1.69)\end{array}$ & $\begin{array}{l}-0.203^{* *} \\
(-1.98)\end{array}$ & $\begin{array}{l}-0.068 * \\
(-1.66)\end{array}$ & $\begin{array}{l}-0.208^{* *} \\
(-1.97)\end{array}$ & & & $\begin{array}{l}-0.068 * \\
(-1.66)\end{array}$ & $\begin{array}{l}-0.208^{* *} \\
(-1.97)\end{array}$ \\
\hline CEO duality & & & $\begin{array}{l}0.000 \\
(0.65)\end{array}$ & $\begin{array}{l}-0.001 \\
(-1.04)\end{array}$ & $\begin{array}{l}0.000 \\
(0.65)\end{array}$ & $\begin{array}{l}-0.001 \\
(-1.04)\end{array}$ & & & $\begin{array}{l}0.000 \\
(0.7)\end{array}$ & $\begin{array}{l}0.000 \\
(0.5)\end{array}$ & $\begin{array}{l}0.000 \\
(0.7)\end{array}$ & $\begin{array}{l}0.000 \\
(0.5)\end{array}$ \\
\hline CEO age & & & $\begin{array}{l}-0.000 \\
(-0.13)\end{array}$ & $\begin{array}{l}-0.007 * * \\
(-2.26)\end{array}$ & $\begin{array}{l}-0.000 \\
(-0.13)\end{array}$ & $\begin{array}{l}-0.007 * * \\
(-2.26)\end{array}$ & & & $\begin{array}{l}-0.001 \\
(-0.5)\end{array}$ & $\begin{array}{l}-0.004 \\
(-1.61)\end{array}$ & $\begin{array}{l}-0.001 \\
(-0.5)\end{array}$ & $\begin{array}{l}-0.004 \\
(-1.61)\end{array}$ \\
\hline Cash pay & & & $\begin{array}{l}0.000 \\
(0.76)\end{array}$ & $\begin{array}{l}0.001 \\
(1.46)\end{array}$ & $\begin{array}{l}0.000 \\
(0.76)\end{array}$ & $\begin{array}{l}0.001 \\
(1.46)\end{array}$ & & & $\begin{array}{l}0.000 \\
(0.89)\end{array}$ & $\begin{array}{l}0.001 \\
(1.28)\end{array}$ & $\begin{array}{l}0.000 \\
(0.89)\end{array}$ & $\begin{array}{l}0.001 \\
(1.28)\end{array}$ \\
\hline
\end{tabular}




\begin{tabular}{|c|c|c|c|c|c|c|c|c|c|c|c|c|}
\hline \multirow[t]{2}{*}{ Equation-level $\mathrm{R}^{2}$} & \multirow{3}{*}{$\begin{array}{l}\text { Delta } \\
0.545^{* * *} \\
(5.54)\end{array}$} & \multirow{3}{*}{$\begin{array}{l}\text { Vega } \\
-0.430^{* * *} \\
(-4.23)\end{array}$} & \multirow[b]{2}{*}{ Delta } & \multirow[b]{2}{*}{ Vega } & \multirow{2}{*}{$\begin{array}{l}0.4142 \\
\text { Delta }\end{array}$} & \multirow{2}{*}{$\begin{array}{l}0.3928 \\
\text { Vega }\end{array}$} & \multirow[b]{2}{*}{ Delta } & \multirow[b]{2}{*}{ Vega } & \multirow[b]{2}{*}{ Delta } & \multirow[b]{2}{*}{ Vega } & \multirow{2}{*}{$\begin{array}{l}0.4151 \\
\text { Delta }\end{array}$} & \multirow{2}{*}{$\begin{array}{l}0.3954 \\
\text { Vega }\end{array}$} \\
\hline & & & & & & & & & & & & \\
\hline Family & & & & & $\begin{array}{l}0.545^{* * *} \\
(5.54)\end{array}$ & $\begin{array}{l}-0.430 * * * \\
(-4.23)\end{array}$ & & & & & & \\
\hline Passive ramily & & & & & & & $(-1.58)$ & $(-2.47)$ & & & $(-1.58)$ & $(-2.47)$ \\
\hline Firm size & $\begin{array}{l}0.240^{* * *} \\
(5)\end{array}$ & $\begin{array}{l}0.141^{* *} \\
(2.48)\end{array}$ & & & $\begin{array}{l}0.240^{* * *} \\
\text { (5) }\end{array}$ & $\begin{array}{l}0.141^{* *} \\
(2.48)\end{array}$ & $\begin{array}{l}0.278^{* * *} \\
(6.35)\end{array}$ & $\begin{array}{l}0.134^{* *} \\
(2.39)\end{array}$ & & & $\begin{array}{l}0.278^{* * *} \\
(6.35)\end{array}$ & $\begin{array}{l}0.134^{* *} \\
(2.39)\end{array}$ \\
\hline CEO duality & $\begin{array}{l}0.467 * * * \\
(4.72)\end{array}$ & $\begin{array}{l}0.242 * * \\
(2.27)\end{array}$ & & & $\begin{array}{l}0.467 * * * \\
(4.72)\end{array}$ & $\begin{array}{l}0.242^{* *} \\
(2.27)\end{array}$ & $\begin{array}{l}0.242^{* * *} \\
(2.62)\end{array}$ & $\begin{array}{l}0.285^{* * * *} \\
(2.67)\end{array}$ & & & $\begin{array}{l}0.242 * * * \\
(2.62)\end{array}$ & $\begin{array}{l}0.285^{* * *} \\
(2.67)\end{array}$ \\
\hline CEO age & $\begin{array}{l}0.872 * * \\
(2.3)\end{array}$ & $\begin{array}{l}-1.110^{* * *} \\
(-2.79)\end{array}$ & & & $\begin{array}{l}0.872^{* *} \\
(2.3)\end{array}$ & $\begin{array}{l}-1.110^{* * *} \\
(-2.79)\end{array}$ & $\begin{array}{l}0.659^{*} \\
(1.94)\end{array}$ & $\begin{array}{l}-1.070^{* * *} \\
(-2.67)\end{array}$ & & & $\begin{array}{l}0.659^{*} \\
(1.94)\end{array}$ & $\begin{array}{l}-1.070^{* * *} \\
(-2.67)\end{array}$ \\
\hline Cash pay & $\begin{array}{l}0.082 \\
(1.06)\end{array}$ & $\begin{array}{l}0.366^{* * *} \\
(2.88)\end{array}$ & & & $\begin{array}{l}0.082 \\
(1.06)\end{array}$ & $\begin{array}{l}0.366^{* * *} \\
(2.88)\end{array}$ & $\begin{array}{l}0.101 \\
(1.31)\end{array}$ & $\begin{array}{l}0.363 * * * \\
(2.89)\end{array}$ & & & $\begin{array}{l}0.101 \\
(1.31)\end{array}$ & $\begin{array}{l}0.363^{* * * *} \\
(2.89)\end{array}$ \\
\hline
\end{tabular}

See Table A.1 for variable definitions.

This table reports structural equation model estimates of corporate investments (measured as the two ratios of capital expenditure and R\&D spending to total assets, respectively). The sample consists of 1,756 firm-year observations that represent 362 unique US small firms during the period of 2001-2005. Active family firm is controlled and run by founding family. Passive family firm is controlled but not run by founding family. Family firm consists of both active and passive family firms. Z-Values are in parentheses and are corrected for serial correlation and heteroskedasticity by clustering on the firm-level identifier. The symbols *, **, and ${ }^{* * *}$ represent statistical significance at the $0.1,0.05$, and 0.01 levels, respectively. 
Table A.5

Family firms, CEO option sensitivities, and M\&A activities

\begin{tabular}{|c|c|c|c|c|c|c|c|c|c|c|c|c|}
\hline & \multicolumn{6}{|c|}{ Model 1} & \multicolumn{6}{|c|}{ Model 2} \\
\hline & \multicolumn{2}{|c|}{ Direct Effect } & \multicolumn{2}{|c|}{ Indirect Effect } & \multicolumn{2}{|c|}{ Total Effect } & \multicolumn{2}{|c|}{ Direct Effect } & \multicolumn{2}{|c|}{ Indirect Effect } & \multicolumn{2}{|c|}{ Total Effect } \\
\hline & Number & Value & Number & Value & Number & Value & Number & Value & Number & Value & Number & Value \\
\hline Family & $\begin{array}{l}0.036 \\
(0.99)\end{array}$ & $\begin{array}{l}0.003 \\
(0.03)\end{array}$ & $\begin{array}{l}-0.013 \\
(-1.25)\end{array}$ & $\begin{array}{l}-0.022 \\
(-0.92)\end{array}$ & $\begin{array}{l}0.023 \\
(0.72)\end{array}$ & $\begin{array}{l}-0.020 \\
(-0.2)\end{array}$ & & & & & & \\
\hline Active family & & & & & & & $\begin{array}{l}-0.016 \\
(-0.34)\end{array}$ & $\begin{array}{l}-0.190 \\
(-1.52)\end{array}$ & $\begin{array}{l}0.004 \\
(0.22)\end{array}$ & $\begin{array}{l}0.050 \\
(1.01)\end{array}$ & $\begin{array}{l}-0.011 \\
(-0.31)\end{array}$ & $\begin{array}{l}-0.140 \\
(-1.35)\end{array}$ \\
\hline Passive family & & & & & & & $\begin{array}{l}0.079 * \\
(1.92)\end{array}$ & $\begin{array}{l}0.166 \\
(1.31)\end{array}$ & $\begin{array}{l}-0.010^{*} \\
(-1.75)\end{array}$ & $\begin{array}{l}-0.025 \\
(-1.54)\end{array}$ & $\begin{array}{l}0.069 * \\
(1.69)\end{array}$ & $\begin{array}{l}0.140 \\
(1.11)\end{array}$ \\
\hline Delta & $\begin{array}{l}0.001 \\
(0.1)\end{array}$ & $\begin{array}{l}0.014 \\
(0.43)\end{array}$ & & & $\begin{array}{l}0.001 \\
(0.1)\end{array}$ & $\begin{array}{l}0.014 \\
(0.43)\end{array}$ & $\begin{array}{l}0.016 \\
(1.16)\end{array}$ & $\begin{array}{l}0.068^{*} \\
(1.84)\end{array}$ & & & $\begin{array}{l}0.016 \\
(1.16)\end{array}$ & $\begin{array}{l}0.068^{*} \\
(1.84)\end{array}$ \\
\hline Vega & $\begin{array}{l}0.031^{* * *} \\
(2.73)\end{array}$ & $\begin{array}{l}0.070^{* *} \\
(2.19)\end{array}$ & & & $\begin{array}{l}0.031^{* * *} \\
(2.73)\end{array}$ & $\begin{array}{l}0.070^{* *} \\
(2.19)\end{array}$ & $\begin{array}{l}0.024^{* *} \\
(2.03)\end{array}$ & $\begin{array}{l}0.045 \\
(1.35)\end{array}$ & & & $\begin{array}{l}0.024^{* *} \\
(2.03)\end{array}$ & $\begin{array}{l}0.045 \\
(1.35)\end{array}$ \\
\hline Firm size & $\begin{array}{l}0.030 \\
(1.56)\end{array}$ & $\begin{array}{l}0.023 \\
(0.46)\end{array}$ & $\begin{array}{l}0.005 \\
(1.36)\end{array}$ & $\begin{array}{l}0.013 \\
(1.34)\end{array}$ & $\begin{array}{l}0.035^{*} \\
(1.87)\end{array}$ & $\begin{array}{l}0.037 \\
(0.74)\end{array}$ & $\begin{array}{l}0.026 \\
(1.36)\end{array}$ & $\begin{array}{l}0.007 \\
(0.14)\end{array}$ & $\begin{array}{l}0.008^{* *} \\
(2.01)\end{array}$ & $\begin{array}{l}0.025^{* *} \\
(2.21)\end{array}$ & $\begin{array}{l}0.033^{*} \\
(1.81)\end{array}$ & $\begin{array}{l}0.032 \\
(0.65)\end{array}$ \\
\hline Tobin's Q & $\begin{array}{l}0.003 \\
(0.19)\end{array}$ & $\begin{array}{l}-0.030 \\
(-0.66)\end{array}$ & $\begin{array}{l}0.005 \\
(0.94)\end{array}$ & $\begin{array}{l}0.018 \\
(1.07)\end{array}$ & $\begin{array}{l}0.008 \\
(0.6)\end{array}$ & $\begin{array}{l}-0.012 \\
(-0.28)\end{array}$ & $\begin{array}{l}-0.004 \\
(-0.26)\end{array}$ & $\begin{array}{l}-0.055 \\
(-1.18)\end{array}$ & $\begin{array}{l}0.011^{*} \\
(1.83)\end{array}$ & $\begin{array}{l}0.040^{* *} \\
(2.17)\end{array}$ & $\begin{array}{l}0.007 \\
(0.54)\end{array}$ & $\begin{array}{l}-0.015 \\
(-0.35)\end{array}$ \\
\hline Firm age & $\begin{array}{l}-0.048^{*} \\
(-1.74)\end{array}$ & $\begin{array}{l}-0.166^{* *} \\
(-2.09)\end{array}$ & & & $\begin{array}{l}-0.048^{*} \\
(-1.74)\end{array}$ & $\begin{array}{l}-0.166^{* *} \\
(-2.09)\end{array}$ & $\begin{array}{l}-0.050 * \\
(-1.84)\end{array}$ & $\begin{array}{l}-0.175^{* *} \\
(-2.2)\end{array}$ & & & $\begin{array}{l}-0.050^{*} \\
(-1.84)\end{array}$ & $\begin{array}{l}-0.175^{* *} \\
(-2.2)\end{array}$ \\
\hline Cash ratio & $\begin{array}{l}-0.499 * * * \\
(-4.15)\end{array}$ & $\begin{array}{l}-1.013 * * * \\
(-2.85)\end{array}$ & & & $\begin{array}{l}-0.499 * * * \\
(-4.15)\end{array}$ & $\begin{array}{l}-1.013^{* * *} \\
(-2.85)\end{array}$ & $\begin{array}{l}-0.499 * * * \\
(-4.15)\end{array}$ & $\begin{array}{l}-1.013 * * * \\
(-2.86)\end{array}$ & & & $\begin{array}{l}-0.499 * * * \\
(-4.15)\end{array}$ & $\begin{array}{l}-1.013^{* * * *} \\
(-2.86)\end{array}$ \\
\hline Leverage ratio & $\begin{array}{l}0.215^{* *} \\
(2.09)\end{array}$ & $\begin{array}{l}1.235^{* * *} \\
(3.57)\end{array}$ & & & $\begin{array}{l}0.215 * * \\
(2.09)\end{array}$ & $\begin{array}{l}1.235^{* * *} \\
(3.57)\end{array}$ & $\begin{array}{l}0.232^{* *} \\
(2.29)\end{array}$ & $\begin{array}{l}1.300^{* * * *} \\
(3.82)\end{array}$ & & & $\begin{array}{l}0.232^{* *} \\
(2.29)\end{array}$ & $\begin{array}{l}1.300 * * * \\
(3.82)\end{array}$ \\
\hline Asset tangibility & $\begin{array}{l}-0.435^{* * * *} \\
(-3.75)\end{array}$ & $\begin{array}{l}-1.191 * * * \\
(-3.88)\end{array}$ & & & $\begin{array}{l}-0.435 * * * \\
(-3.75)\end{array}$ & $\begin{array}{l}-1.191 * * * \\
(-3.88)\end{array}$ & $\begin{array}{l}-0.445^{* * *} \\
(-3.79)\end{array}$ & $\begin{array}{l}-1.229 * * * \\
(-4.06)\end{array}$ & & & $\begin{array}{l}-0.445^{* * *} \\
(-3.79)\end{array}$ & $\begin{array}{l}-1.229 * * * \\
(-4.06)\end{array}$ \\
\hline Dividend ratio & $\begin{array}{l}-1.413^{* * *} \\
(-4.02)\end{array}$ & $\begin{array}{l}-3.635^{* * * *} \\
(-3.37)\end{array}$ & & & $\begin{array}{l}-1.413^{* * * *} \\
(-4.02)\end{array}$ & $\begin{array}{l}-3.635^{* * *} \\
(-3.37)\end{array}$ & $\begin{array}{l}-1.451 * * * \\
(-4.07)\end{array}$ & $\begin{array}{l}-3.777 * * * \\
(-3.47)\end{array}$ & & & $\begin{array}{l}-1.451^{* * *} \\
(-4.07)\end{array}$ & $\begin{array}{l}-3.777 * * * \\
(-3.47)\end{array}$ \\
\hline CEO duality & & & $\begin{array}{l}0.008 \\
(1.23)\end{array}$ & $\begin{array}{l}0.023 \\
(1.29)\end{array}$ & $\begin{array}{l}0.008 \\
(1.23)\end{array}$ & $\begin{array}{l}0.023 \\
(1.29)\end{array}$ & & & $\begin{array}{l}0.011^{* *} \\
(2.19)\end{array}$ & $\begin{array}{l}0.029 * * \\
(2.04)\end{array}$ & $\begin{array}{l}0.011^{* *} \\
(2.19)\end{array}$ & $\begin{array}{l}0.029 * * \\
(2.04)\end{array}$ \\
\hline CEO age & & & $\begin{array}{l}-0.033 \\
(-1.44)\end{array}$ & $\begin{array}{l}-0.065 \\
(-1.23)\end{array}$ & $\begin{array}{l}-0.033 \\
(-1.44)\end{array}$ & $\begin{array}{l}-0.065 \\
(-1.23)\end{array}$ & & & $\begin{array}{l}-0.016 \\
(-0.71)\end{array}$ & $\begin{array}{l}-0.004 \\
(-0.07)\end{array}$ & $\begin{array}{l}-0.016 \\
(-0.71)\end{array}$ & $\begin{array}{l}-0.004 \\
(-0.07)\end{array}$ \\
\hline Cash pay & & & $\begin{array}{l}0.011^{* *} \\
(2.02)\end{array}$ & $\begin{array}{l}0.027^{*} \\
(1.72)\end{array}$ & $\begin{array}{l}0.011^{* *} \\
(2.02)\end{array}$ & $\begin{array}{l}0.027^{*} \\
(1.72)\end{array}$ & & & $\begin{array}{l}0.010^{*} \\
(1.83)\end{array}$ & $\begin{array}{l}0.023 \\
(1.47)\end{array}$ & $\begin{array}{l}0.010^{*} \\
(1.83)\end{array}$ & $\begin{array}{l}0.023 \\
(1.47)\end{array}$ \\
\hline
\end{tabular}


Industry and Year F.E.

See Table A.1 for variable definitions.

This table reports structural equation model estimates of M\&A activities. M\&A activities are measured as $\ln (1+\mathrm{M} \& \mathrm{~A}$ number) and $\ln (1+\operatorname{sum}$ of M\&A deal value), respectively. The sample consists of 1,756 firm-year observations that represent 362 unique US small firms during the period of 2001-2005. Active family firm is controlled and run by founding family. Passive family firm is controlled but not run by founding family. Family firm consists of both active and passive family firms. Z-Values are in parentheses and are corrected for serial correlation and heteroskedasticity by clustering on the firm-level identifier. All specifications control for industry (1-digit SIC codes) and year fixed effects. The symbols *, **, and *** represent statistical significance at the $0.1,0.05$, and 0.01 levels, respectively. 
Figure A.2 Scatter plots of vega and delta in three types of family firms
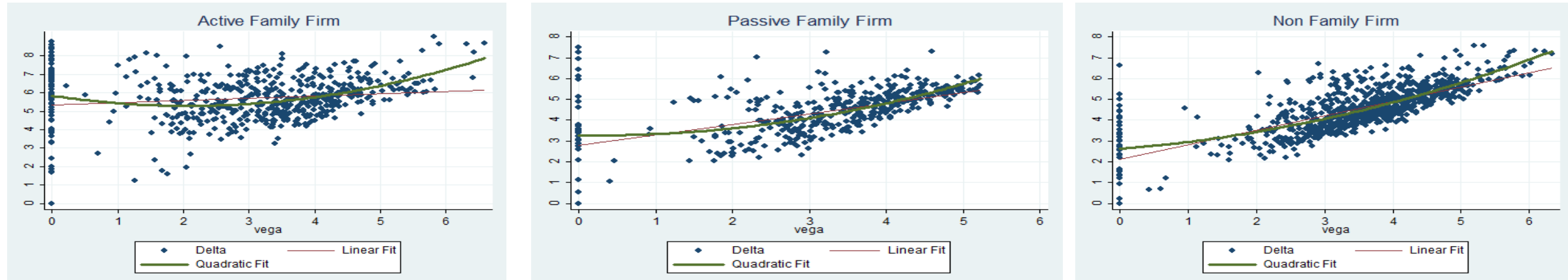

Figure A.3 Contour plots of vega, delta, and R\&D in three types of family firms
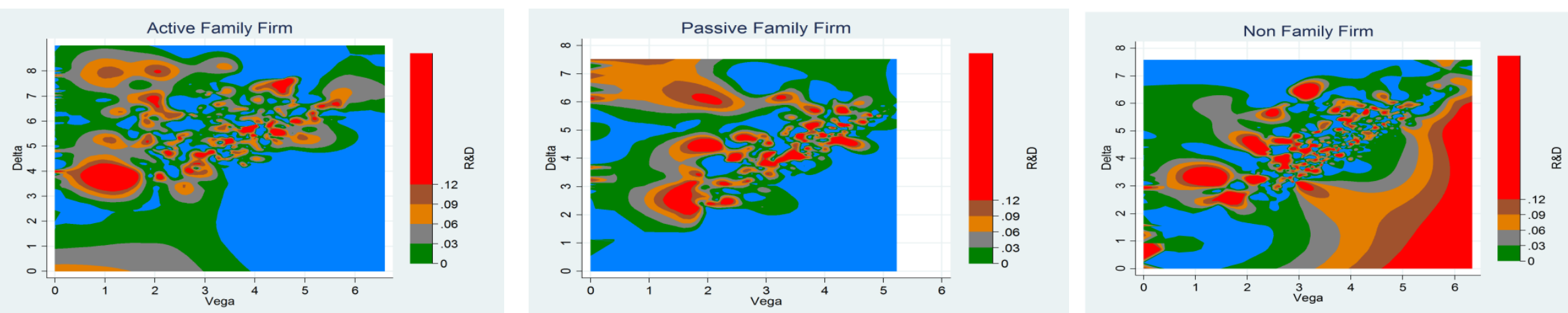

Figure A.4 Contour plots of vega, delta, and M\&A number in three types of family firms
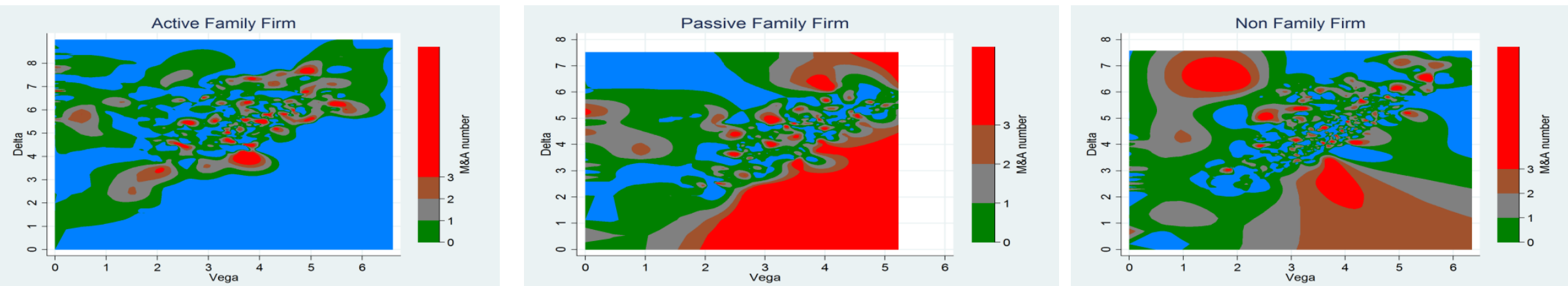
Table A.6

Family firms, CEO option sensitivities, and corporate investments (contingent on risks)

\begin{tabular}{|c|c|c|c|c|c|c|c|c|c|c|c|c|}
\hline \multicolumn{13}{|l|}{ Panel A: firm risk } \\
\hline & \multicolumn{6}{|c|}{ Low (below median risk) } & \multicolumn{6}{|c|}{ High (above median risk) } \\
\hline & \multicolumn{2}{|c|}{ Direct Effect } & \multicolumn{2}{|c|}{ Indirect Effect } & \multicolumn{2}{|c|}{ Total Effect } & \multicolumn{2}{|c|}{ Direct Effect } & \multicolumn{2}{|c|}{ Indirect Effect } & \multicolumn{2}{|c|}{ Total Effect } \\
\hline & CAPEX & R\&D & CAPEX & $\mathrm{R} \& \mathrm{D}$ & CAPEX & R\&D & CAPEX & $\mathrm{R} \& \mathrm{D}$ & CAPEX & $\mathrm{R} \& \mathrm{D}$ & CAPEX & R\&D \\
\hline \multirow[t]{2}{*}{ Active family } & 0.004 & -0.002 & 0.003 & -0.001 & 0.007 & -0.003 & 0.007 & -0.013 & $-0.005^{*}$ & -0.002 & 0.002 & $-0.015^{*}$ \\
\hline & $(0.45)$ & $(-0.48)$ & $(1.43)$ & $(-0.52)$ & $(0.83)$ & $(-0.93)$ & $(1.33)$ & $(-1.46)$ & $(-1.89)$ & $(-0.48)$ & $(0.38)$ & $(-1.88)$ \\
\hline \multirow[t]{2}{*}{ Passive family } & 0.004 & 0.005 & -0.001 & -0.001 & 0.003 & 0.004 & -0.000 & 0.009 & 0.000 & 0.000 & -0.000 & 0.009 \\
\hline & (1) & $(0.9)$ & $(-0.79)$ & $(-1.59)$ & $(0.85)$ & $(0.73)$ & $(-0.05)$ & $(0.89)$ & $(0.27)$ & $(0.41)$ & $(-0.03)$ & $(0.91)$ \\
\hline \multirow[t]{2}{*}{ Delta } & 0.003 & 0.000 & & & 0.003 & 0.000 & $-0.004 *$ & -0.002 & & & $-0.004^{*}$ & -0.002 \\
\hline & (1.58) & $(0.18)$ & & & (1.58) & (0.18) & $(-1.81)$ & $(-0.56)$ & & & $(-1.81)$ & $(-0.56)$ \\
\hline \multirow[t]{2}{*}{ Vega } & -0.000 & 0.003 & & & -0.000 & 0.003 & 0.002 & -0.000 & & & 0.002 & -0.000 \\
\hline & $(-0.13)$ & (1.55) & & & $(-0.13)$ & (1.55) & $(0.92)$ & $(-0.13)$ & & & $(0.92)$ & $(-0.13)$ \\
\hline \multirow[t]{2}{*}{ Equation-level $\mathrm{R}^{2}$} & & & & & 0.4103 & 0.2783 & & & & & 0.5167 & 0.4037 \\
\hline & Delta & Vega & Delta & Vega & Delta & Vega & Delta & Vega & Delta & Vega & Delta & Vega \\
\hline \multirow[t]{2}{*}{ Active family } & $0.981^{* * *}$ & $-0.550 * * *$ & & & $0.981^{* * *}$ & $-0.550 * * *$ & $1.094^{* * *}$ & $-0.367 * * *$ & & & $1.094 * * *$ & $-0.367 * * *$ \\
\hline & (5.67) & $(-2.95)$ & & & (5.67) & $(-2.95)$ & (8.76) & $(-2.61)$ & & & (8.76) & $(-2.61)$ \\
\hline \multirow[t]{2}{*}{ Passive family } & -0.233 & $-0.333 * *$ & & & -0.233 & $-0.333 * *$ & -0.090 & -0.164 & & & -0.090 & -0.164 \\
\hline & $(-1.59)$ & $(-2.28)$ & & & $(-1.59)$ & $(-2.28)$ & $(-0.78)$ & $(-1.26)$ & & & $(-0.78)$ & $(-1.26)$ \\
\hline Equation-level $\mathrm{R}^{2}$ & & & & & 0.3168 & 0.2433 & & & & & 0.4308 & 0.0871 \\
\hline \multicolumn{13}{|l|}{ Industry and Year F.E. } \\
\hline \& control variables & & & & & & Yes & & & & & & Yes \\
\hline Model $\mathrm{R}^{2}$ & & & & & & 0.7749 & & & & & & 0.8463 \\
\hline \# of obs. & & & & & & 839 & & & & & & 838 \\
\hline
\end{tabular}

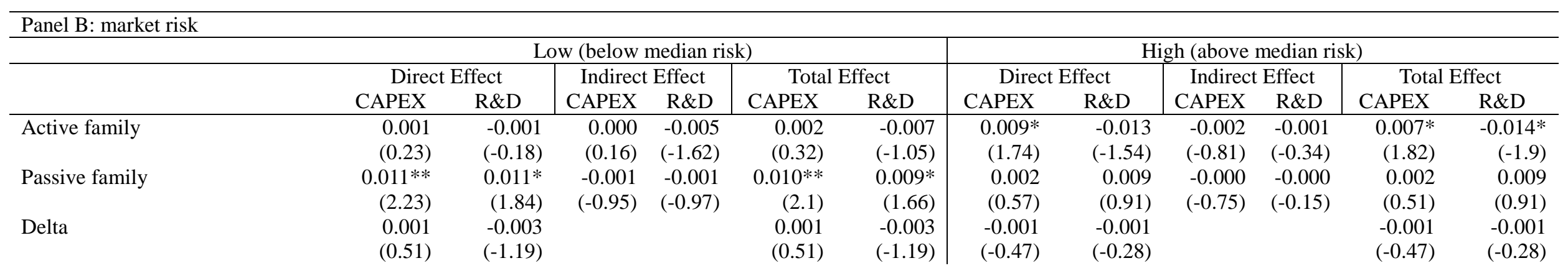




\begin{tabular}{|c|c|c|c|c|c|c|c|c|c|c|c|c|}
\hline \multirow{3}{*}{$\begin{array}{l}\text { Vega } \\
\text { Equation-level } \mathrm{R}^{2}\end{array}$} & $\begin{array}{r}0.001 \\
(0.96)\end{array}$ & $\begin{array}{r}0.005 * * \\
(2.5)\end{array}$ & & & $\begin{array}{r}0.001 \\
(0.96)\end{array}$ & $\begin{array}{r}0.005^{* *} \\
(2.5)\end{array}$ & $\begin{array}{r}0.002 \\
(1.24)\end{array}$ & $\begin{array}{r}0.001 \\
(0.35)\end{array}$ & & & $\begin{array}{r}0.002 \\
(1.24)\end{array}$ & $\begin{array}{r}0.001 \\
(0.35)\end{array}$ \\
\hline & & & & & 0.5458 & 0.3904 & & & & & 0.4910 & 0.4257 \\
\hline & Delta & Vega & Delta & Vega & Delta & Vega & Delta & Vega & Delta & Vega & Delta & Vega \\
\hline Active family & $\begin{array}{r}0.911^{* * *} \\
(5.11)\end{array}$ & $\begin{array}{r}-0.512 * * \\
(-2.52)\end{array}$ & & & $\begin{array}{r}0.911 * * * \\
(5.11)\end{array}$ & $\begin{array}{r}-0.512 * * \\
(-2.52)\end{array}$ & $\begin{array}{r}1.197 * * * \\
(8.4)\end{array}$ & $\begin{array}{r}-0.468 * * * \\
(-2.62)\end{array}$ & & & $\begin{array}{r}1.197 * * * \\
(8.4)\end{array}$ & $\begin{array}{r}-0.468 * * * \\
(-2.62)\end{array}$ \\
\hline Passive family & $\begin{array}{r}-0.384 * * \\
(-2.12)\end{array}$ & $\begin{array}{r}-0.486 * * * \\
(-2.77)\end{array}$ & & & $\begin{array}{r}-0.384 * * \\
(-2.12)\end{array}$ & $\begin{array}{r}-0.486 * * * \\
(-2.77)\end{array}$ & $\begin{array}{l}-0.101 \\
(-0.84)\end{array}$ & $\begin{array}{r}-0.153 \\
(-1.1)\end{array}$ & & & $\begin{array}{l}-0.101 \\
(-0.84)\end{array}$ & $\begin{array}{r}-0.153 \\
(-1.1)\end{array}$ \\
\hline $\begin{array}{l}\text { Equation-level } \mathrm{R}^{2} \\
\text { Industry and Year F.E. }\end{array}$ & & & & & 0.3257 & 0.1890 & & & & & 0.3629 & 0.1038 \\
\hline \& control variables & & & & & & Yes & & & & & & Yes \\
\hline Model R ${ }^{2}$ & & & & & & 0.8455 & & & & & & 0.8275 \\
\hline \# of obs. & & & & & & 699 & & & & & & 699 \\
\hline
\end{tabular}

\begin{tabular}{|c|c|c|c|c|c|c|c|c|c|c|c|c|}
\hline \multicolumn{13}{|l|}{ Panel C: idiosyncratic risk } \\
\hline & \multicolumn{6}{|c|}{ Low (below median risk) } & \multicolumn{6}{|c|}{ High (above median risk) } \\
\hline & \multicolumn{2}{|c|}{ Direct Effect } & \multicolumn{2}{|c|}{ Indirect Effect } & \multicolumn{2}{|c|}{ Total Effect } & \multicolumn{2}{|c|}{ Direct Effect } & \multicolumn{2}{|c|}{ Indirect Effect } & \multicolumn{2}{|c|}{ Total Effect } \\
\hline & CAPEX & R\&D & CAPEX & $\mathrm{R} \& \mathrm{D}$ & CAPEX & R\&D & CAPEX & $\mathrm{R} \& \mathrm{D}$ & CAPEX & $\mathrm{R} \& \mathrm{D}$ & CAPEX & R\&D \\
\hline Active family & $\begin{array}{c}0.003 \\
(0.44)\end{array}$ & $\begin{array}{l}-0.004 \\
(-0.76)\end{array}$ & $\begin{array}{r}0.001 \\
(0.43)\end{array}$ & $\begin{array}{l}-0.002 \\
(-0.83)\end{array}$ & $\begin{array}{c}0.003 \\
(0.74)\end{array}$ & $\begin{array}{l}-0.007 \\
(-1.32)\end{array}$ & $\begin{array}{c}0.007 \\
(1.21)\end{array}$ & $\begin{array}{r}-0.005 \\
(-0.59)\end{array}$ & $\begin{array}{r}-0.001 \\
(-0.6)\end{array}$ & $\begin{array}{c}-0.003 \\
(-0.88)\end{array}$ & $\begin{array}{r}0.005 \\
(1.14)\end{array}$ & $\begin{array}{l}-0.008 \\
(-1.03)\end{array}$ \\
\hline Passive family & $\begin{array}{l}0.006 \\
(1.29)\end{array}$ & $\begin{array}{r}0.001 \\
(0.26)\end{array}$ & $\begin{array}{l}-0.001 \\
(-0.99)\end{array}$ & $\begin{array}{r}-0.002^{*} \\
(-1.81)\end{array}$ & $\begin{array}{l}0.005 \\
(1.15)\end{array}$ & $\begin{array}{l}-0.001 \\
(-0.14)\end{array}$ & $\begin{array}{c}0.007 \\
(1.49)\end{array}$ & $\begin{array}{r}0.020^{*} \\
(1.88)\end{array}$ & $\begin{array}{l}-0.000 \\
(-0.75)\end{array}$ & $\begin{array}{r}0.000 \\
(0.2)\end{array}$ & $\begin{array}{r}0.007 \\
(1.44)\end{array}$ & $\begin{array}{r}0.020^{*} \\
(1.9)\end{array}$ \\
\hline Delta & $\begin{array}{l}0.001 \\
(0.69)\end{array}$ & $\begin{array}{l}-0.000 \\
(-0.21)\end{array}$ & & & $\begin{array}{l}0.001 \\
(0.69)\end{array}$ & $\begin{array}{l}-0.000 \\
(-0.21)\end{array}$ & $\begin{array}{l}-0.000 \\
(-0.18)\end{array}$ & $\begin{array}{l}-0.002 \\
(-0.83)\end{array}$ & & & $\begin{array}{l}-0.000 \\
(-0.18)\end{array}$ & $\begin{array}{l}-0.002 \\
(-0.83)\end{array}$ \\
\hline Vega & $\begin{array}{l}0.001 \\
(0.51)\end{array}$ & $\begin{array}{r}0.004^{* *} \\
(2.54)\end{array}$ & & & $\begin{array}{l}0.001 \\
(0.51)\end{array}$ & $\begin{array}{r}0.004^{* *} \\
(2.54)\end{array}$ & $\begin{array}{r}0.002^{*} \\
(1.66)\end{array}$ & $\begin{array}{r}0.001 \\
(0.5)\end{array}$ & & & $\begin{array}{r}0.002^{*} \\
(1.66)\end{array}$ & $\begin{array}{r}0.001 \\
(0.5)\end{array}$ \\
\hline Equation-level $\mathrm{R}^{2}$ & & & & & 0.5321 & 0.3813 & & & & & 0.5083 & 0.4136 \\
\hline & Delta & Vega & Delta & Vega & Delta & Vega & Delta & Vega & Delta & Vega & Delta & Vega \\
\hline Active family & $\begin{array}{r}1.069 * * * \\
(5.91)\end{array}$ & $\begin{array}{r}-0.427 * * \\
(-2.12)\end{array}$ & & & $\begin{array}{r}1.069 * * * \\
(5.91)\end{array}$ & $\begin{array}{r}-0.427 * * \\
(-2.12)\end{array}$ & $\begin{array}{r}1.113 * * * \\
(8.13)\end{array}$ & $\begin{array}{r}-0.439 * * * \\
(-2.79)\end{array}$ & & & $\begin{array}{r}1.113^{* * *} \\
(8.13)\end{array}$ & $\begin{array}{r}-0.439 * * * \\
(-2.79)\end{array}$ \\
\hline Passive family & $\begin{array}{r}-0.400 * * \\
(-2.26)\end{array}$ & $\begin{array}{r}-0.505 * * * \\
(-2.91)\end{array}$ & & & $\begin{array}{r}-0.400 * * \\
(-2.26)\end{array}$ & $\begin{array}{r}-0.505 * * * \\
(-2.91)\end{array}$ & $\begin{array}{r}-0.096 \\
(-0.8)\end{array}$ & $\begin{array}{r}-0.128 \\
(-0.96)\end{array}$ & & & $\begin{array}{r}-0.096 \\
(-0.8)\end{array}$ & $\begin{array}{r}-0.128 \\
(-0.96)\end{array}$ \\
\hline $\begin{array}{l}\text { Equation-level } \mathrm{R}^{2} \\
\text { Industry and Year F.E. }\end{array}$ & & & & & 0.2946 & 0.1780 & & & & & 0.4010 & 0.0808 \\
\hline $\begin{array}{l}\text { \& control variables } \\
\text { Model } \mathrm{R}^{2}\end{array}$ & & & & & & $\begin{array}{r}\text { Yes } \\
0.8284\end{array}$ & & & & & & $\begin{array}{r}\text { Yes } \\
0.8368\end{array}$ \\
\hline
\end{tabular}


See Table A.1 for variable definitions.

This table uses three risk measures and reports separate structural equation model estimates of long-term corporate investments (measured as the two ratios of capital expenditure and R\&D spending to total assets, respectively). The sample consists of 1,756 firm-year observations that represent 362 unique US small firms during the period of 2001-2005. Active family firm is controlled and run by founding family. Passive family firm is controlled but not run by founding family. Family firm consists of both active and passive family firms. Z-Values are in parentheses and are corrected for serial correlation and heteroskedasticity by clustering on the firm-level identifier. The symbols $*$, **, and $* * *$ represent statistical significance at the $0.1,0.05$, and 0.01 levels, respectively. 
Table A.7

Family firms, CEO option sensitivities, and M\&A activities (contingent on firm risks)

\begin{tabular}{|c|c|c|c|c|c|c|c|c|c|c|c|c|}
\hline \multicolumn{13}{|l|}{ Panel A: firm risk } \\
\hline & \multicolumn{6}{|c|}{ Low (below median risk) } & \multicolumn{6}{|c|}{ High (above median risk) } \\
\hline & \multicolumn{2}{|c|}{ Direct Effect } & \multicolumn{2}{|c|}{ Indirect Effect } & \multicolumn{2}{|c|}{ Total Effect } & \multicolumn{2}{|c|}{ Direct Effect } & \multicolumn{2}{|c|}{ Indirect Effect } & \multicolumn{2}{|c|}{ Total Effect } \\
\hline & Number & Value & Number & Value & Number & Value & Number & Value & Number & Value & Number & Value \\
\hline \multirow[t]{2}{*}{ Active family } & -0.038 & -0.173 & 0.012 & 0.081 & -0.025 & -0.092 & 0.025 & -0.107 & 0.004 & 0.019 & 0.029 & -0.088 \\
\hline & $(-0.57)$ & $(-0.88)$ & $(0.51)$ & $(1.08)$ & $(-0.45)$ & $(-0.54)$ & $(0.43)$ & $(-0.59)$ & $(0.13)$ & $(0.23)$ & $(0.62)$ & $(-0.63)$ \\
\hline \multirow[t]{2}{*}{ Passive family } & $0.138 * *$ & $0.432 * *$ & -0.006 & -0.029 & $0.132 * *$ & $0.403 * *$ & 0.031 & -0.022 & -0.009 & -0.018 & 0.022 & -0.039 \\
\hline & (2.24) & (2.31) & $(-0.98)$ & $(-1.22)$ & (2.17) & (2.19) & $(0.63)$ & $(-0.13)$ & $(-1.09)$ & $(-0.95)$ & $(0.44)$ & $(-0.24)$ \\
\hline \multirow[t]{2}{*}{ Delta } & 0.017 & $0.094 *$ & & & 0.017 & $0.094 *$ & 0.019 & 0.045 & & & 0.019 & 0.045 \\
\hline & $(0.92)$ & $(1.74)$ & & & $(0.92)$ & $(1.74)$ & $(0.86)$ & $(0.66)$ & & & $(0.86)$ & $(0.66)$ \\
\hline \multirow[t]{2}{*}{ Vega } & 0.007 & 0.020 & & & 0.007 & 0.020 & $0.046 * *$ & 0.082 & & & $0.046 * *$ & 0.082 \\
\hline & $(0.43)$ & $(0.36)$ & & & $(0.43)$ & $(0.36)$ & (2.37) & (1.37) & & & (2.37) & $(1.37)$ \\
\hline Equation-level $\mathrm{R}^{2}$ & & & & & 0.1174 & 0.0834 & & & & & 0.1006 & 0.0540 \\
\hline \multicolumn{13}{|l|}{ Industry and Year F.E. } \\
\hline \& control variables & & & & & & Yes & & & & & & Yes \\
\hline Model $\mathrm{R}^{2}$ & & & & & & 0.5539 & & & & & & 0.5402 \\
\hline \# of obs. & & & & & & 839 & & & & & & 838 \\
\hline
\end{tabular}

\begin{tabular}{|c|c|c|c|c|c|c|c|c|c|c|c|c|}
\hline \multicolumn{13}{|l|}{ Panel B: market risk } \\
\hline & \multicolumn{6}{|c|}{ Low (below median risk) } & \multicolumn{6}{|c|}{ High (above median risk) } \\
\hline & \multicolumn{2}{|c|}{ Direct Effect } & \multicolumn{2}{|c|}{ Indirect Effect } & \multicolumn{2}{|c|}{ Total Effect } & \multicolumn{2}{|c|}{ Direct Effect } & \multicolumn{2}{|c|}{ Indirect Effect } & \multicolumn{2}{|c|}{ Total Effect } \\
\hline & Number & Value & Number & Value & Number & Value & Number & Value & Number & Value & Number & Value \\
\hline Active family & $\begin{array}{r}0.044 \\
(0.67)\end{array}$ & $\begin{array}{r}-0.156 \\
(-0.9)\end{array}$ & $\begin{array}{r}0.001 \\
(0.04)\end{array}$ & $\begin{array}{r}0.038 \\
(0.54)\end{array}$ & $\begin{array}{r}0.044 \\
(0.78)\end{array}$ & $\begin{array}{l}-0.118 \\
(-0.78)\end{array}$ & $\begin{array}{l}-0.053 \\
(-0.84)\end{array}$ & $\begin{array}{l}-0.305 \\
(-1.51)\end{array}$ & $\begin{array}{r}0.028 \\
(0.99)\end{array}$ & $\begin{array}{r}0.125 \\
(1.4)\end{array}$ & $\begin{array}{l}-0.025 \\
(-0.49)\end{array}$ & $\begin{array}{l}-0.180 \\
(-1.09)\end{array}$ \\
\hline Passive family & $\begin{aligned} 0.116^{*} \\
(1.95)\end{aligned}$ & $\begin{array}{r}0.251 \\
(1.32)\end{array}$ & $\begin{array}{l}-0.020 \\
(-1.62)\end{array}$ & $\begin{array}{l}-0.048 \\
(-1.36)\end{array}$ & $\begin{array}{r}0.096 \\
(1.62)\end{array}$ & $\begin{array}{r}0.203 \\
(1.08)\end{array}$ & $\begin{array}{r}0.046 \\
(0.75)\end{array}$ & $\begin{array}{l}-0.047 \\
(-0.25)\end{array}$ & $\begin{array}{l}-0.003 \\
(-0.65)\end{array}$ & $\begin{array}{l}-0.011 \\
(-0.64)\end{array}$ & $\begin{array}{r}0.043 \\
(0.71)\end{array}$ & $\begin{array}{l}-0.059 \\
(-0.31)\end{array}$ \\
\hline Delta & $\begin{array}{r}0.017 \\
(0.88)\end{array}$ & $\begin{array}{r}0.067 \\
(1.1)\end{array}$ & & & $\begin{array}{r}0.017 \\
(0.88)\end{array}$ & $\begin{array}{r}0.067 \\
(1.1)\end{array}$ & $\begin{array}{r}0.024 \\
(1.18)\end{array}$ & $\begin{array}{r}0.106 \\
(1.57)\end{array}$ & & & $\begin{array}{r}0.024 \\
(1.18)\end{array}$ & $\begin{array}{r}0.106 \\
(1.57)\end{array}$ \\
\hline Vega & $\begin{array}{r}0.029 \\
(1.61)\end{array}$ & $\begin{array}{r}0.045 \\
(0.89)\end{array}$ & & & $\begin{array}{r}0.029 \\
(1.61)\end{array}$ & $\begin{array}{r}0.045 \\
(0.89)\end{array}$ & $\begin{array}{r}0.002 \\
(0.1)\end{array}$ & $\begin{array}{r}0.004 \\
(0.07)\end{array}$ & & & $\begin{array}{r}0.002 \\
(0.1)\end{array}$ & $\begin{array}{r}0.004 \\
(0.07)\end{array}$ \\
\hline $\begin{array}{l}\text { Equation-level } \mathrm{R}^{2} \\
\text { Industry and Year F.E. }\end{array}$ & & & & & 0.1125 & 0.0809 & & & & & 0.0970 & 0.0727 \\
\hline \& control variables & & & & & & Yes & & & & & & Yes \\
\hline Model $\mathrm{R}^{2}$ & & & & & & 0.5322 & & & & & & 0.5001 \\
\hline \# of obs. & & & & & & 699 & & & & & & 699 \\
\hline
\end{tabular}




\begin{tabular}{|c|c|c|c|c|c|c|c|c|c|c|c|c|}
\hline \multicolumn{13}{|c|}{ Panel C: idiosyncratic risk } \\
\hline & \multicolumn{6}{|c|}{ Low (below median risk) } & \multicolumn{6}{|c|}{ High (above median risk) } \\
\hline & \multicolumn{2}{|c|}{ Direct Effect } & \multicolumn{2}{|c|}{ Indirect Effect } & \multicolumn{2}{|c|}{ Total Effect } & \multicolumn{2}{|c|}{ Direct Effect } & \multicolumn{2}{|c|}{ Indirect Effect } & \multicolumn{2}{|c|}{ Total Effect } \\
\hline & Number & Value & Number & Value & Number & Value & Number & Value & Number & Value & Number & Value \\
\hline \multirow[t]{2}{*}{ Active family } & -0.018 & -0.288 & 0.027 & $0.174 *$ & 0.009 & -0.114 & 0.012 & -0.117 & 0.010 & 0.004 & 0.022 & -0.113 \\
\hline & $(-0.28)$ & $(-1.38)$ & $(1.04)$ & $(1.96)$ & $(0.15)$ & $(-0.59)$ & $(0.19)$ & $(-0.67)$ & $(0.39)$ & $(0.05)$ & $(0.43)$ & $(-0.78)$ \\
\hline \multirow[t]{2}{*}{ Passive family } & $0.138 * *$ & 0.231 & -0.013 & -0.029 & $0.125^{*}$ & 0.202 & 0.005 & -0.056 & -0.005 & -0.015 & -0.000 & -0.071 \\
\hline & (2.07) & $(1.15)$ & $(-1.12)$ & $(-0.72)$ & $(1.89)$ & $(1.03)$ & $(0.1)$ & $(-0.33)$ & $(-0.84)$ & $(-0.84)$ & $(-0.01)$ & $(-0.42)$ \\
\hline \multirow[t]{2}{*}{ Delta } & 0.027 & $0.141^{* *}$ & & & 0.027 & $0.141^{* *}$ & 0.019 & 0.039 & & & 0.019 & 0.039 \\
\hline & $(1.32)$ & (2.09) & & & $(1.32)$ & (2.09) & $(0.96)$ & $(0.65)$ & & & $(0.96)$ & $(0.65)$ \\
\hline \multirow[t]{2}{*}{ Vega } & 0.004 & -0.055 & & & 0.004 & -0.055 & 0.026 & $0.090 *$ & & & 0.026 & $0.090^{*}$ \\
\hline & $(0.24)$ & $(-0.87)$ & & & $(0.24)$ & $(-0.87)$ & $(1.43)$ & (1.8) & & & $(1.43)$ & (1.8) \\
\hline Equation-level $\mathrm{R}^{2}$ & & & & & 0.1476 & 0.1194 & & & & & 0.0960 & 0.0638 \\
\hline \multicolumn{13}{|l|}{ Industry and Year F.E. } \\
\hline \& control variables & & & & & & Yes & & & & & & Yes \\
\hline Model $\mathrm{R}^{2}$ & & & & & & 0.5287 & & & & & & 0.5085 \\
\hline \# of obs. & & & & & & 699 & & & & & & 699 \\
\hline
\end{tabular}

See Table A.1 for variable definitions.

This table uses three risk measures and reports separate structural equation model estimates of M\&A activities. M\&A activities are measured as ln(1+M\&A number) and $\ln (1+$ sum of M\&A deal value), respectively. The sample consists of 1,756 firm-year observations that represent 362 unique US small firms during the period of $2001-2005$. Active family firm is controlled and run by founding family. Passive family firm is controlled but not run by founding family. Family firm consists of both active and passive family firms. Z-Values are in parentheses and are corrected for serial correlation and heteroskedasticity by clustering on the firm-level identifier. All specifications control for industry (1-digit SIC codes) and year fixed effects. The symbols *, **, and *** represent statistical significance at the $0.1,0.05$, and 0.01 levels, respectively. 
Table A.8

Robustness Checks: R\&D outcomes

\begin{tabular}{llrrrrr}
\hline Panel A: R\&D input and output & & & & & \\
\hline & & Mean & Min. & P50 & Max. & Number of obs. \\
\hline R\&D missing & Patents filed & 0.37 & 0 & 0 & 19 & 626 \\
& Patent citation & 1.71 & 0 & 0 & 79 & 626 \\
R\&D =0 & Patents filed & 0.01 & 0 & 0 & 1 & 235 \\
& Patent citation & 0.02 & 0 & 0 & 3 & 235 \\
R\&D $>0$ & Patents filed & 4.41 & 0 & 1 & 83 & 895 \\
& Patent citation & 30.76 & 0 & 0 & 1,511 & 895 \\
\hline
\end{tabular}

\begin{tabular}{llrrr}
\hline \multicolumn{2}{l}{ Panel B: R\&D input/output and family firms } & & & \\
\hline \multicolumn{2}{c}{ Active Family Firms } & Passive Family Firms & Non Family firms \\
\hline R\&D missing & Patents filed & 0.22 & 0.35 & 0.50 \\
& Patent citation & 0.74 & 1.33 & 2.56 \\
\multirow{5}{*}{ R\&D =0 } & \% of obs. & $33.87 \%$ & $19.17 \%$ & $46.96 \%$ \\
& Patents filed & 0.00 & 0.02 & 0.01 \\
& Patent citation & 0.00 & 0.05 & 0.01 \\
R\&D $>0$ & \% of obs. & $27.66 \%$ & $23.40 \%$ & $48.94 \%$ \\
& Patents filed & 3.70 & 4.94 & 4.60 \\
& Patent citation & 30.22 & 34.52 & 29.09 \\
& \% of obs. & $30.06 \%$ & $24.58 \%$ & $45.36 \%$ \\
\hline
\end{tabular}

\begin{tabular}{|c|c|c|c|c|c|c|}
\hline \multicolumn{7}{|l|}{ Panel C: Patents } \\
\hline & \multicolumn{2}{|c|}{ Direct Effect } & \multicolumn{2}{|c|}{ Indirect Effect } & \multicolumn{2}{|c|}{ Total Effect } \\
\hline & Number & Citation & Number & Citation & Number & Citation \\
\hline \multirow[t]{2}{*}{ Active family } & -0.170 & $-0.306 *$ & 0.034 & 0.076 & -0.136 & -0.231 \\
\hline & $(-1.64)$ & $(-1.75)$ & $(0.75)$ & (1) & $(-1.46)$ & $(-1.48)$ \\
\hline \multirow[t]{2}{*}{ Passive family } & 0.077 & 0.112 & -0.019 & -0.027 & 0.058 & 0.085 \\
\hline & $(0.72)$ & (0.68) & $(-1.55)$ & $(-1.42)$ & $(0.55)$ & $(0.51)$ \\
\hline \multirow[t]{2}{*}{ Delta } & 0.048 & 0.089 & & & 0.048 & 0.089 \\
\hline & (1.45) & (1.61) & & & $(1.45)$ & (1.61) \\
\hline \multirow[t]{2}{*}{ Vega } & 0.034 & 0.040 & & & 0.034 & 0.040 \\
\hline & $(1.21)$ & (0.83) & & & $(1.21)$ & (0.83) \\
\hline \multirow[t]{2}{*}{ Firm size } & $-0.106 * *$ & $-0.209 * * *$ & $0.018 * *$ & $0.030 * *$ & $-0.088 *$ & $-0.179 * *$ \\
\hline & $(-2.13)$ & $(-2.62)$ & (1.99) & $(2.06)$ & $(-1.8)$ & $(-2.28)$ \\
\hline \multirow[t]{2}{*}{ Tobin’s Q } & 0.004 & -0.014 & $0.028 *$ & $0.049 * *$ & 0.032 & 0.035 \\
\hline & $(0.09)$ & $(-0.21)$ & (1.89) & $(1.98)$ & $(0.74)$ & $(0.5)$ \\
\hline \multirow[t]{2}{*}{ Firm age } & $-0.132 *$ & $-0.203^{*}$ & & & $-0.132 *$ & $-0.203 *$ \\
\hline & $(-1.8)$ & $(-1.73)$ & & & $(-1.8)$ & $(-1.73)$ \\
\hline \multirow[t]{2}{*}{ Cash ratio } & 0.081 & 0.046 & & & 0.081 & 0.046 \\
\hline & $(0.23)$ & (0.08) & & & $(0.23)$ & (0.08) \\
\hline \multirow[t]{2}{*}{ Leverage ratio } & 0.236 & 0.302 & & & 0.236 & 0.302 \\
\hline & $(0.95)$ & $(0.69)$ & & & $(0.95)$ & $(0.69)$ \\
\hline \multirow[t]{2}{*}{ Asset tangibility } & $-0.474 * *$ & $-0.799 * *$ & & & $-0.474 * *$ & $-0.799 * *$ \\
\hline & $(-2.14)$ & $(-2.29)$ & & & $(-2.14)$ & $(-2.29)$ \\
\hline \multirow[t]{2}{*}{ Dividend ratio } & -2.141 & -2.988 & & & -2.141 & -2.988 \\
\hline & $(-0.97)$ & $(-0.86)$ & & & $(-0.97)$ & $(-0.86)$ \\
\hline \multirow[t]{2}{*}{ CEO duality } & & & $0.021 * *$ & $0.033 * *$ & $0.021 * *$ & $0.033^{* *}$ \\
\hline & & & $(2.07)$ & $(1.98)$ & $(2.07)$ & $(1.98)$ \\
\hline \multirow[t]{2}{*}{ CEO age } & & & -0.005 & 0.016 & -0.005 & 0.016 \\
\hline & & & $(-0.1)$ & (0.19) & $(-0.1)$ & $(0.19)$ \\
\hline \multirow[t]{2}{*}{ Cash pay } & & & 0.017 & 0.023 & 0.017 & 0.023 \\
\hline & & & $(1.46)$ & (1.23) & $(1.46)$ & $(1.23)$ \\
\hline Equation-level $\mathrm{R}^{2}$ & & & & & 0.2063 & 0.1938 \\
\hline Industry and Year F.E. & & & & & & Yes \\
\hline Model $\mathrm{R}^{2}$ & & & & & & 0.5704 \\
\hline \# of obs. & & & & & & 1,756 \\
\hline
\end{tabular}


Table A.9

Robustness Checks: alternative model estimations

\begin{tabular}{|c|c|c|c|c|c|c|c|c|c|c|}
\hline & \multirow{2}{*}{\multicolumn{3}{|c|}{ Tobit model }} & \multirow{2}{*}{\multicolumn{3}{|c|}{$\begin{array}{c}\text { Heckman model } \\
\text { (control for self-selection) }\end{array}$}} & \multicolumn{4}{|c|}{ Tobit model (IV) } \\
\hline & & & & & & & $1^{\text {st }}$ stage: & $2^{\text {nd }}$ stage: & $1^{\text {st }}$ stage: & $2^{\text {nd }}$ stage: \\
\hline & Model 1 & Model 2 & Model 3 & Model 4 & Model 5 & Model 6 & Model 7 & Model 8 & Model 9 & Model 10 \\
\hline Delta & $\begin{array}{r}-0.008^{* *} \\
(-2.41)\end{array}$ & $\begin{array}{l}-0.006 \\
(-1.62)\end{array}$ & $\begin{array}{r}-0.006^{*} \\
(-1.68)\end{array}$ & $\begin{array}{r}-0.007 * * * \\
(-3.63)\end{array}$ & $\begin{array}{r}-0.005 * * * \\
(-2.69)\end{array}$ & $\begin{array}{r}-0.006 * * * \\
(-3.28)\end{array}$ & & & & \\
\hline Vega & $\begin{array}{r}0.007 * * \\
(2.31)\end{array}$ & $\begin{array}{r}0.006 * * \\
(2.14)\end{array}$ & $\begin{array}{r}0.007 * * \\
(2.31)\end{array}$ & $\begin{array}{r}0.003 \\
(1.6)\end{array}$ & $\begin{array}{r}0.002 \\
(1.4)\end{array}$ & $\begin{array}{r}0.002 \\
(1.26)\end{array}$ & $\begin{array}{r}0.240 * * * \\
(8.44)\end{array}$ & $\begin{array}{r}0.011^{* * *} \\
(4.92)\end{array}$ & $\begin{array}{r}0.180^{* * *} \\
(6.76)\end{array}$ & $\begin{array}{l}-0.001 \\
(-0.51)\end{array}$ \\
\hline Vega*Family & $\begin{array}{l}0.001 \\
(0.57)\end{array}$ & & & $\begin{array}{l}-0.000 \\
(-0.04)\end{array}$ & & & & & & \\
\hline Vega*Active family & & $\begin{array}{l}-0.002 \\
(-0.81)\end{array}$ & & & $\begin{array}{l}-0.002 \\
(-1.44)\end{array}$ & & & $\begin{array}{r}-0.025 * * * \\
(-4.07)\end{array}$ & & \\
\hline Vega*Passive family & & $\begin{array}{r}0.005^{*} \\
(1.82)\end{array}$ & & & $\begin{array}{r}0.002 \\
(1.3)\end{array}$ & & & & & $\begin{array}{r}0.035^{* * *} \\
(3.99)\end{array}$ \\
\hline Vega*Active family ownership & & & $\begin{array}{l}-0.001 \\
(-0.86)\end{array}$ & & & $\begin{array}{r}0.000 \\
(0.2)\end{array}$ & & & & \\
\hline Vega*Passive family ownership & & & $\begin{array}{r}0.002 \\
(1)\end{array}$ & & & $\begin{array}{r}0.002 * \\
(1.94)\end{array}$ & & & & \\
\hline Firm size & $\begin{array}{r}-0.030 * * * \\
(-6.04)\end{array}$ & $\begin{array}{r}-0.031 * * * \\
(-6.36)\end{array}$ & $\begin{array}{r}-0.031 * * * \\
(-6.08)\end{array}$ & $\begin{array}{r}-0.021 * * * \\
(-3.92)\end{array}$ & $\begin{array}{r}-0.022 * * * \\
(-3.98)\end{array}$ & $\begin{array}{r}-0.021 * * * \\
(-3.73)\end{array}$ & $\begin{array}{l}-0.052 \\
(-1.14)\end{array}$ & $\begin{array}{r}-0.033 * * * \\
(-13.24)\end{array}$ & $\begin{array}{r}0.080^{*} \\
(1.88)\end{array}$ & $\begin{array}{r}-0.035 * * * \\
(-12.91)\end{array}$ \\
\hline Tobin's Q & $\begin{array}{r}0.014 * * * \\
(2.96)\end{array}$ & $\begin{array}{r}0.012 * * * \\
(2.66)\end{array}$ & $\begin{array}{r}0.013 * * * \\
(2.8)\end{array}$ & $\begin{array}{r}0.009 * * * \\
(4.48)\end{array}$ & $\begin{array}{r}0.009 * * * \\
(4.17)\end{array}$ & $\begin{array}{r}0.009 * * * \\
(4.37)\end{array}$ & $\begin{array}{l}-0.000 \\
(-0.01)\end{array}$ & $\begin{array}{r}0.010^{* * *} \\
(4.57)\end{array}$ & $\begin{array}{r}0.089 * * \\
(2.22)\end{array}$ & $\begin{array}{r}0.007 * * * \\
(2.8)\end{array}$ \\
\hline Firm age & $\begin{array}{l}-0.009 \\
(-1.38)\end{array}$ & $\begin{array}{r}-0.010 \\
(-1.5)\end{array}$ & $\begin{array}{l}-0.010 \\
(-1.56)\end{array}$ & $\begin{array}{r}-0.012 * * * \\
(-3.04)\end{array}$ & $\begin{array}{r}-0.013 * * * \\
(-3.24)\end{array}$ & $\begin{array}{r}-0.012 * * * \\
(-3.13)\end{array}$ & $\begin{array}{r}-0.456 * * * \\
(-7.66)\end{array}$ & $\begin{array}{r}-0.018^{* * *} \\
(-4.39)\end{array}$ & $\begin{array}{r}-0.009 \\
(-0.15)\end{array}$ & $\begin{array}{r}-0.007^{*} \\
(-1.89)\end{array}$ \\
\hline Cash ratio & $\begin{array}{r}0.048 \\
(1.43)\end{array}$ & $\begin{array}{c}0.045 \\
(1.36)\end{array}$ & $\begin{array}{r}0.046 \\
(1.36)\end{array}$ & $\begin{array}{r}0.037 * * \\
(2.3)\end{array}$ & $\begin{array}{r}0.035^{* *} \\
(2.19)\end{array}$ & $\begin{array}{r}0.035^{* *} \\
(2.22)\end{array}$ & $\begin{array}{l}-0.355 \\
(-0.99)\end{array}$ & $\begin{array}{r}0.038^{* *} \\
(2.07)\end{array}$ & $\begin{array}{r}0.077 \\
(0.23)\end{array}$ & $\begin{array}{r}0.043^{* *} \\
(2.23)\end{array}$ \\
\hline Leverage ratio & $\begin{array}{l}-0.011 \\
(-0.45)\end{array}$ & $\begin{array}{r}-0.005 \\
(-0.2)\end{array}$ & $\begin{array}{r}-0.008 \\
(-0.33)\end{array}$ & $\begin{array}{r}0.011 \\
(0.88)\end{array}$ & $\begin{array}{r}0.015 \\
(1.19)\end{array}$ & $\begin{array}{r}0.011 \\
(0.91)\end{array}$ & $\begin{array}{l}0.148 \\
(0.58)\end{array}$ & $\begin{array}{r}0.004 \\
(0.3)\end{array}$ & $\begin{array}{r}-0.190 \\
(-0.8)\end{array}$ & $\begin{array}{r}0.007 \\
(0.44)\end{array}$ \\
\hline Asset tangibility & $\begin{array}{r}-0.103 * * * \\
(-3.96)\end{array}$ & $\begin{array}{r}-0.106 * * * \\
(-4.09)\end{array}$ & $\begin{array}{r}-0.104 * * * \\
(-4.01)\end{array}$ & $\begin{array}{r}-0.093 * * * \\
(-4.05)\end{array}$ & $\begin{array}{r}-0.091 * * * \\
(-3.98)\end{array}$ & $\begin{array}{r}-0.093 * * * \\
(-4.03)\end{array}$ & $\begin{array}{l}-0.128 \\
(-0.55)\end{array}$ & $\begin{array}{r}-0.107 * * * \\
(-6.9)\end{array}$ & $\begin{array}{r}0.365^{*} \\
(1.68)\end{array}$ & $\begin{array}{r}-0.119 * * * \\
(-7.27)\end{array}$ \\
\hline Dividend ratio & $\begin{array}{l}-0.349 \\
(-1.55)\end{array}$ & $\begin{array}{l}-0.360 \\
(-1.55)\end{array}$ & $\begin{array}{l}-0.342 \\
(-1.53)\end{array}$ & $\begin{array}{r}-0.136 \\
(-1.41)\end{array}$ & $\begin{array}{r}-0.126 \\
(-1.31)\end{array}$ & $\begin{array}{l}-0.127 \\
(-1.32)\end{array}$ & $\begin{array}{l}-1.355 \\
(-0.76)\end{array}$ & $\begin{array}{r}-0.363 * * * \\
(-3.63)\end{array}$ & $\begin{array}{r}4.899 * * * \\
(2.93)\end{array}$ & $\begin{array}{r}-0.499 * * * \\
(-4.36)\end{array}$ \\
\hline CEO duality & & & & $\begin{array}{r}-0.010^{* * *} \\
(-2.63)\end{array}$ & $\begin{array}{r}-0.009 * * \\
(-2.29)\end{array}$ & $\begin{array}{r}-0.009 * * \\
(-2.53)\end{array}$ & $\begin{array}{r}0.662 * * * \\
(8.97)\end{array}$ & & $\begin{array}{r}-0.488 * * * \\
(-7.05)\end{array}$ & \\
\hline
\end{tabular}




\begin{tabular}{|c|c|c|c|c|c|c|c|c|c|c|}
\hline $\begin{array}{l}\text { Industry and Year F.E. } \\
\text { Adjusted } \mathrm{R}^{2}\end{array}$ & Yes & Yes & Yes & Yes & Yes & Yes & $\begin{array}{r}\text { Yes } \\
0.1301\end{array}$ & Yes & $\begin{array}{r}\text { Yes } \\
0.0681\end{array}$ & Yes \\
\hline F-test & $13.90^{* * *}$ & $13.23 * * *$ & $13.40 * * *$ & & & & $12.93 * * *$ & & $6.83^{* * *}$ & \\
\hline Wald Chi^2 & & & & $168.64 * * *$ & $175.68 * * *$ & $174.07 * * *$ & & $742.63^{* * *}$ & & $679.67 * * *$ \\
\hline Mill’s lambda & & & & $\begin{array}{r}0.0128 \\
(0.76)\end{array}$ & $\begin{array}{r}0.0098 \\
(0.58)\end{array}$ & $\begin{array}{r}0.0090 \\
(0.53)\end{array}$ & & & & \\
\hline Wald test of exogeneity & & & & & & & & $12.60 * * *$ & & $14.21 * * *$ \\
\hline \# of obs. & 1,756 & 1,756 & 1,756 & 1,753 & 1,753 & 1,753 & 1,756 & 1,756 & 1,756 & 1,756 \\
\hline
\end{tabular}

See Table A.1 for variable definitions. This table reports robustness checks on the relations between family incentive pay and long-term corporate investments (measured as the patent number/citation in Panel A and the ratio of R\&D spending to total assets in Panel B). The sample consists of 1,756 firm-year observations that represent 362 unique US small firms during the period of 2001-2005. Active family firm is controlled and run by founding family. Passive family firm is controlled but not run by founding family. Family firm consists of both active and passive family firms. In Panel A, Z-Values are in parentheses and are corrected for serial correlation and heteroskedasticity by clustering on the firm-level identifier. In Panel B Models 1-6, T-Values (Z-Values for the Heckman models) are in parentheses and are corrected for serial correlation and heteroskedasticity by clustering on the firm-level identifier (except for the three Heckman models). In Panel B Models 7-10, T-Values (for the first stage estimates) and ZValues (for the second stage estimates) are in parentheses. The symbols *, **, and *** represent statistical significance at the $0.1,0.05$, and 0.01 levels, respectively.

Figure A.5

Contour plots of firm age, family ownership, and vega in three types of family firms
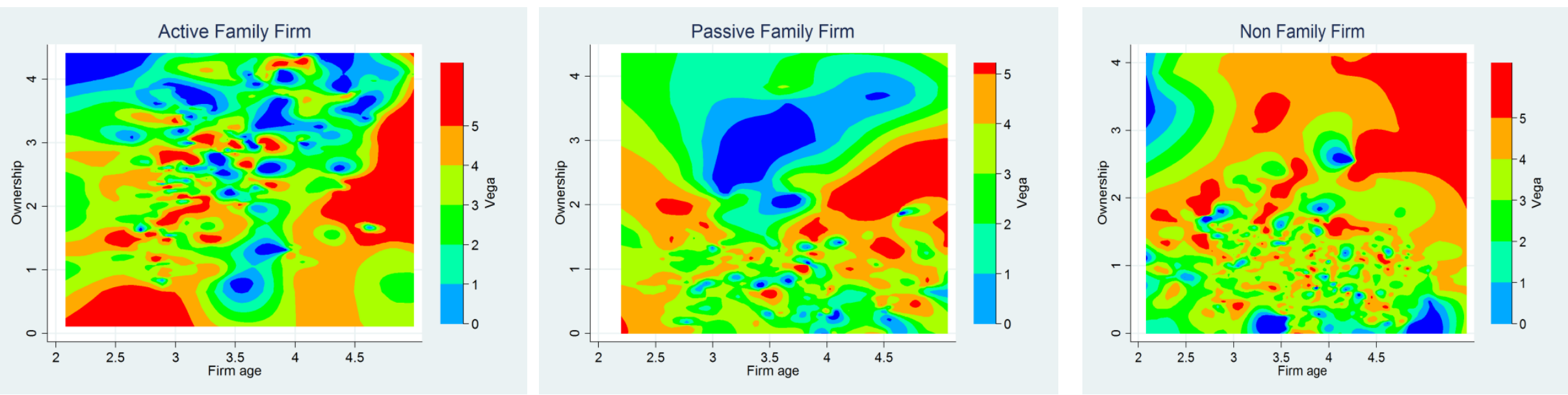